\title{
A new method for atmospheric detection of the $\mathrm{CH}_{3} \mathrm{O}_{2}$ radical
}

\author{
Lavinia Onel $^{1}$, Alexander Brennan ${ }^{1}$, Paul W. Seakins ${ }^{1,2}$, Lisa Whalley ${ }^{1,2}$, and Dwayne E. Heard ${ }^{1,2}$ \\ ${ }^{1}$ School of Chemistry, University of Leeds, Leeds, LS2 9JT, UK \\ ${ }^{2}$ National Centre for Atmospheric Science, University of Leeds, LS2 9JT, UK \\ Correspondence to: Lavinia Onel (chmlo@leeds.ac.uk) and Dwayne Heard (d.e.heard@leeds.ac.uk)
}

Received: 19 April 2017 - Discussion started: 16 May 2017

Revised: 21 September 2017 - Accepted: 22 September 2017 - Published: 27 October 2017

\begin{abstract}
A new method for measurement of the methyl peroxy $\left(\mathrm{CH}_{3} \mathrm{O}_{2}\right)$ radical has been developed using the conversion of $\mathrm{CH}_{3} \mathrm{O}_{2}$ into $\mathrm{CH}_{3} \mathrm{O}$ by excess $\mathrm{NO}$ with subsequent detection of $\mathrm{CH}_{3} \mathrm{O}$ by fluorescence assay by gas expansion (FAGE) with laser excitation at ca. $298 \mathrm{~nm}$. The method can also directly detect $\mathrm{CH}_{3} \mathrm{O}$, when no nitric oxide is added. Laboratory calibrations were performed to characterise the FAGE instrument sensitivity using the conventional radical source employed in $\mathrm{OH}$ calibration with conversion of a known concentration of $\mathrm{OH}$ into $\mathrm{CH}_{3} \mathrm{O}_{2}$ via reaction with $\mathrm{CH}_{4}$ in the presence of $\mathrm{O}_{2}$. Detection limits of $3.8 \times 10^{8}$ and $3.0 \times 10^{8}$ molecule $\mathrm{cm}^{-3}$ were determined for $\mathrm{CH}_{3} \mathrm{O}_{2}$ and $\mathrm{CH}_{3} \mathrm{O}$ respectively for a signal-to-noise ratio of 2 and $5 \mathrm{~min}$ averaging time. Averaging over $1 \mathrm{~h}$ reduces the detection limit for $\mathrm{CH}_{3} \mathrm{O}_{2}$ to $1.1 \times 10^{8}$ molecule $\mathrm{cm}^{-3}$, which is comparable to atmospheric concentrations. The kinetics of the second-order decay of $\mathrm{CH}_{3} \mathrm{O}_{2}$ via its self-reaction were observed in HIRAC (Highly Instrumented Reactor for Atmospheric Chemistry) at $295 \mathrm{~K}$ and 1 bar and used as an alternative method of calibration to obtain a calibration constant with overlapping error limits at the $1 \sigma$ level with the result of the conventional method of calibration. The overall uncertainties of the two methods of calibrations are similar - $15 \%$ for the kinetic method and $17 \%$ for the conventional method - and are discussed in detail. The capability to quantitatively measure $\mathrm{CH}_{3} \mathrm{O}$ in chamber experiments is demonstrated via observation in HIRAC of $\mathrm{CH}_{3} \mathrm{O}$ formed as a product of the $\mathrm{CH}_{3} \mathrm{O}_{2}$ self-reaction.
\end{abstract}

\section{Introduction}

Methyl peroxy $\left(\mathrm{CH}_{3} \mathrm{O}_{2}\right)$ radicals are critical intermediates in the atmospheric oxidation (Orlando and Tyndall, 2012) and combustion of hydrocarbons (Zador et al., 2011). In the remote atmosphere, $\mathrm{CH}_{3} \mathrm{O}_{2}$ is mainly formed by the reaction of methane with the $\mathrm{OH}$ radical via abstraction of an $\mathrm{H}$ atom (Reaction R1), followed by the reaction of the produced $\mathrm{CH}_{3}$ radical with $\mathrm{O}_{2}$ (Reaction $\mathrm{R} 2$ ).

$$
\begin{aligned}
& \mathrm{OH}+\mathrm{CH}_{4} \rightarrow \mathrm{CH}_{3}+\mathrm{H}_{2} \mathrm{O} \\
& \mathrm{CH}_{3}+\mathrm{O}_{2}+\mathrm{M} \rightarrow \mathrm{CH}_{3} \mathrm{O}_{2}+\mathrm{M}
\end{aligned}
$$

Methyl peroxy radicals can also be formed from more complex species, e.g. the reaction of acetyl peroxy radicals with $\mathrm{HO}_{2}$ in low- $\mathrm{NO}_{x}$ environments or the reaction of acetyl peroxy radicals with $\mathrm{NO}$ in anthropogenically influenced environments. $\mathrm{CH}_{3} \mathrm{O}_{2}$ is predicted to be the most abundant peroxy radical in the atmosphere, yet there are no specific measurements of its concentration. Daytime concentrations estimated using a box model utilising the MCM (Master Chemical Mechanism) version 3.3.1 (Saunders et al., 2003; Jenkin et al., 2015) are $\sim 6 \times 10^{8}$ molecule $\mathrm{cm}^{-3}$ in the tropical Atlantic Ocean in summer (Whalley et al., 2010), $\sim 2 \times 10^{8}$ molecule $\mathrm{cm}^{-3}$ in a tropical rainforest (Whalley et al., 2011) and lower in polluted environments, for example $\sim 5 \times 10^{7}$ molecule $\mathrm{cm}^{-3}$ in London in summertime (Whalley et al., 2017).

The reaction of $\mathrm{CH}_{3} \mathrm{O}_{2}$ with $\mathrm{NO}$ (Reaction R3) usually dominates the chemistry of $\mathrm{CH}_{3} \mathrm{O}_{2}$, particularly in environments influenced by anthropogenic $\mathrm{NO}_{x}$ emissions, resulting in $\mathrm{NO}_{2}$ production and hence ozone production: 


$$
\mathrm{CH}_{3} \mathrm{O}_{2}+\mathrm{NO} \rightarrow \mathrm{CH}_{3} \mathrm{O}+\mathrm{NO}_{2} \text {. }
$$

The subsequent reaction of $\mathrm{CH}_{3} \mathrm{O}$ with $\mathrm{O}_{2}$ (Reaction R4) produces $\mathrm{HO}_{2}$, which in turn oxidises another $\mathrm{NO}$ to $\mathrm{NO}_{2}$ (Reaction R5) with further production of $\mathrm{O}_{3}$ and propagation of the $\mathrm{HO}_{x}$ radical chain:

$$
\begin{aligned}
& \mathrm{CH}_{3} \mathrm{O}+\mathrm{O}_{2} \rightarrow \mathrm{CH}_{2} \mathrm{O}+\mathrm{HO}_{2}, \\
& \mathrm{HO}_{2}+\mathrm{NO} \rightarrow \mathrm{OH}+\mathrm{NO}_{2} .
\end{aligned}
$$

However, under low $\mathrm{NO}_{x}$ levels (e.g. remote forested environments and the marine boundary layer), the self-reaction of $\mathrm{CH}_{3} \mathrm{O}_{2}$ (Reaction R6) and the reactions of $\mathrm{CH}_{3} \mathrm{O}_{2}$ with $\mathrm{HO}_{2}$ and other organic peroxy $\left(\mathrm{RO}_{2}\right)$ species are important radical removal/termination reactions. The $\mathrm{CH}_{3} \mathrm{O}_{2}$ self-reaction occurs through two channels, Reactions (R6a) and (R6b) (Tyndall et al., 1998):

$$
\begin{aligned}
& \mathrm{CH}_{3} \mathrm{O}_{2}+\mathrm{CH}_{3} \mathrm{O}_{2} \rightarrow \mathrm{CH}_{3} \mathrm{OH}+\mathrm{CH}_{2} \mathrm{O}+\mathrm{O}_{2}, \\
& \mathrm{CH}_{3} \mathrm{O}_{2}+\mathrm{CH}_{3} \mathrm{O}_{2} \rightarrow \mathrm{CH}_{3} \mathrm{O}+\mathrm{CH}_{3} \mathrm{O}+\mathrm{O}_{2} .
\end{aligned}
$$

Despite the importance of Reaction (R6), there are uncertainties of about a factor of 2 in the value of its rate coefficient at room temperature, $k_{6}$, which has a range of $(2.7-5.2) \times 10^{-13} \mathrm{~cm}^{3}$ molecule ${ }^{-1} \mathrm{~s}^{-1}$ (Atkinson et al., 2006); the preferred IUPAC value is $k_{6}=$ $3.5 \times 10^{-13} \mathrm{~cm}^{3}$ molecule ${ }^{-1} \mathrm{~s}^{-1}$. The previous kinetic studies used time-resolved UV-absorption spectroscopy to detect $\mathrm{CH}_{3} \mathrm{O}_{2}$ radical, typically at $250 \mathrm{~nm}$, (Sander and Watson, 1980, 1981; McAdam et al., 1987; Kurylo and Wallington, 1987; Jenkin et al., 1988; Simon et al., 1990; Lightfoot et al., 1990). UV-absorption spectroscopy is a relatively insensitive technique and hence the detection limits of $\mathrm{CH}_{3} \mathrm{O}_{2}$ were quite high, for example approximately $4 \times 10^{12}$ molecule $\mathrm{cm}^{-3}$ (Sander and Watson, 1980, 1981). In addition, due to the broad, featureless spectra of $\mathrm{RO}_{2}$ species, which often overlap, UV absorption is a relatively unselective technique for the study of the kinetics of individual $\mathrm{RO}_{2}$. Therefore, there is a clear need for the determination of $k_{6}$ using a more selective method, which will be addressed in subsequent studies.

At present, $\mathrm{CH}_{3} \mathrm{O}_{2}$ is not specifically measured in the atmosphere by any direct or indirect method. Time-resolved continuous-wave cavity ring-down spectroscopy (CRDS), using the $v_{12}$ transition of the $A \leftarrow X$ band at $\sim 1.3 \mu \mathrm{m}$, has been used to detect $\mathrm{CH}_{3} \mathrm{O}_{2}$ directly in a photoreactor (Farago et al., 2013; Bossolasco et al., 2014). However, the detection limit is not sufficiently sensitive to enable tropospheric detection. Typically, the sum of $\mathrm{HO}_{2}$ and all organic $\mathrm{RO}_{2}$ has been measured in the atmosphere, making no distinction between $\mathrm{HO}_{2}$ and different $\mathrm{RO}_{2}$ species, although more recently the sum of $\mathrm{RO}_{2}$ has been quantified separately from $\mathrm{HO}_{2}$. One of the methods uses chemical ionisation mass spectrometry to determine the sum $\left[\mathrm{HO}_{2}\right]+\sum_{i}\left[\mathrm{RO}_{2, i}\right]$ or separately $\left[\mathrm{HO}_{2}\right]$, depending on the control of the flows of the $\mathrm{NO}$ and $\mathrm{SO}_{2}$ reagents (Hanke et al., 2002; Edwards et al., 2003). The sum $\left[\mathrm{HO}_{2}\right]+\sum_{i}\left[\mathrm{RO}_{2, i}\right]$ has also been determined for many years by the peroxy radical chemical amplifier (PERCA) method, which uses $\mathrm{NO}$ and $\mathrm{CO}$ to generate $\mathrm{NO}_{2}$ amplified by a chain reaction, and subsequently measured by a variety of methods, for example luminol fluorescence, laser-induced fluorescence (LIF) or cavity absorption methods (Cantrell and Stedman, 1982; Cantrell et al., 1984; Miyazaki et al., 2010; Hernandez et al., 2001; Green et al., 2006; Chen et al., 2016). A modification of PERCA, using a denuder to remove $\mathrm{HO}_{2}$ has been used to estimate the sum of $\mathrm{RO}_{2}$ (Miyazaki et al., 2010). $\mathrm{RO}_{x}$ LIF is a more recent method, which uses OH LIF detection at low pressure, known as FAGE (fluorescence assay by gas expansion) (Fuchs et al., 2008; Whalley et al., 2013). The $\mathrm{RO}_{x} \mathrm{LIF}$ method measures either $\left[\mathrm{HO}_{x}\right]=[\mathrm{OH}]+\left[\mathrm{HO}_{2}\right]$, by converting $\mathrm{HO}_{x}$ into $\mathrm{HO}_{2}$ through addition of $\mathrm{CO}$, or $\left[\mathrm{RO}_{x}\right]=\left[\mathrm{HO}_{x}\right]+\sum_{i}\left(\left[\mathrm{RO}_{2, i}\right]+\left[\mathrm{RO}_{i}\right]\right)$, by titrating $\mathrm{RO}_{x}$ to $\mathrm{HO}_{2}$ by added $\mathrm{NO}$ and $\mathrm{CO}$. After the conversion into $\mathrm{HO}_{2}$, $\mathrm{HO}_{2}$ is converted into $\mathrm{OH}$ in the FAGE chamber and detected by LIF. The sum $\sum_{i}\left[\mathrm{RO}_{2, i}\right]$ and the concentration of the initial $\mathrm{HO}_{2}$ can be determined from the separate measurements of $\mathrm{HO}_{x}, \mathrm{RO}_{x}$ and $\mathrm{OH}$. The limit of detection (LOD) of the $\mathrm{RO}_{x}$ LIF method is $\sim 0.1 \mathrm{pptv}\left(2.5 \times 10^{6}\right.$ molecule $\left.\mathrm{cm}^{-3}\right)$ (Fuchs et al., 2008; Whalley et al., 2013). Recently, the interference from certain types of $\mathrm{RO}_{2}$ radicals in the FAGE detection of $\mathrm{HO}_{2}$ was deliberately exploited to enable a partial $\mathrm{RO}_{2}$ speciation (Whalley et al., 2013). The method was used in the Clean Air for London campaign (ClearfLo) to distinguish between the sum of alkene, aromatic, and longchain alkane-derived $\mathrm{RO}_{2}$ radicals and the sum of short-chain alkane-derived $\mathrm{RO}_{2}$ radicals (Whalley et al., 2013).

As methoxy $\left(\mathrm{CH}_{3} \mathrm{O}\right)$ radicals can be generated by techniques such as pulsed laser photolysis and microwave discharge and detected with high sensitivity by LIF (Shannon et al., 2013; Chai et al., 2014; Albaladejo et al., 2002; Biggs et al., 1993, 1997), the method has been used in kinetic studies of a range of $\mathrm{CH}_{3} \mathrm{O}$ reactions. These studies used the electronic excitation of the methoxy radical from the ground state to the first electronically excited state $\left(A^{2} A_{1} \leftarrow X^{2} E\right)$. The $A \leftarrow X$ excitation spectrum covers the range $\sim 275-317 \mathrm{~nm}$ and leads to fluorescence from several vibronic bands in the near UV, which has been reported in a series of experimental and theoretical studies (Inoue et al., 1980; Kappert and Temps, 1989; Powers et al., 1997; Nagesh et al., 2014).

This paper reports the development of a new method for the selective and sensitive detection of $\mathrm{CH}_{3} \mathrm{O}_{2}$ radicals using FAGE by titrating $\mathrm{CH}_{3} \mathrm{O}_{2}$ to $\mathrm{CH}_{3} \mathrm{O}$ by reaction with added $\mathrm{NO}$ (Reaction R3) and then detecting the resultant $\mathrm{CH}_{3} \mathrm{O}$ by off-resonant LIF with laser excitation at ca. $298 \mathrm{~nm}$. The method is similar to the standard method used for the detection of $\mathrm{HO}_{2}$ radicals by FAGE through conversion of $\mathrm{HO}_{2}$ to $\mathrm{OH}$ by reaction with added $\mathrm{NO}$ followed by $\mathrm{OH}$ on- 
resonance LIF at about $308 \mathrm{~nm}$ (Heard and Pilling, 2003). As LIF is not an absolute detection method, FAGE instruments require calibration, with the $184.9 \mathrm{~nm}$ photolysis of water vapour in air using a mercury $(\mathrm{Hg})$ Pen-Ray lamp being a common method employed for generating known concentrations of $\mathrm{OH}$ and $\mathrm{HO}_{2}$ (Heard and Pilling, 2003):

$\mathrm{H}_{2} \mathrm{O} \stackrel{184.9 \mathrm{~nm}}{\longrightarrow} \mathrm{OH}+\mathrm{H}$,

$\mathrm{H}+\mathrm{O}_{2}+\mathrm{M} \rightarrow \mathrm{HO}_{2}+\mathrm{M}$,

where $\mathrm{M}=\mathrm{N}_{2}, \mathrm{O}_{2}$ and the photodissociation quantum yield of $\mathrm{OH}$ and $\mathrm{H}$ is unity. In this study the photolysis of water vapour is performed in the presence of excess methane to produce $\mathrm{CH}_{3} \mathrm{O}_{2}$ :

$$
\begin{aligned}
& \mathrm{CH}_{4}+\mathrm{OH} \rightarrow \mathrm{CH}_{3}+\mathrm{H}_{2} \mathrm{O}, \\
& \mathrm{CH}_{3}+\mathrm{O}_{2}+\mathrm{M} \rightarrow \mathrm{CH}_{3} \mathrm{O}_{2}+\mathrm{M} .
\end{aligned}
$$

An alternative $\mathrm{CH}_{3} \mathrm{O}_{2}$ calibration is also presented, consisting of the analysis of the kinetics of the $\mathrm{CH}_{3} \mathrm{O}_{2}$ decay by selfreaction monitored by FAGE and compared with the water photolysis method. The studies are performed within HIRAC (Highly Instrumented Reactor for Atmospheric Chemistry), which is a $2.25 \mathrm{~m}^{3}$, custom-built, stainless steel chamber simulating the ambient conditions (Glowacki et al., 2007). HIRAC has been used in alternative calibrations of FAGE for $\mathrm{OH}$ and $\mathrm{HO}_{2}$ using the temporal evolution of appropriate species, in validation and development of new atmospheric measurement techniques as well as in kinetic and mechanistic studies of atmospheric relevant reactions (Malkin et al., 2010; Winiberg et al., 2015, 2016).

Direct LIF detection of $\mathrm{CH}_{3} \mathrm{O}$ radicals, which is also a key intermediate in the oxidation of methane and other volatile organic compounds (VOCs) in the troposphere and formed by reactions such as Reactions (R3) and (R6b), is also reported here. However, in the atmosphere, $\mathrm{CH}_{3} \mathrm{O}$ is exclusively consumed by reaction with $\mathrm{O}_{2}$ (Reaction $\mathrm{R} 4$ ) generating formaldehyde and recycling $\mathrm{HO}_{2}$, resulting in a very short lifetime and consequently very low concentration $\left(\sim 10^{2}-10^{3}\right.$ molecule $\left.\mathrm{cm}^{-3}\right)$. For this reason no measurements in the atmosphere have previously been attempted. The photolysis of $\mathrm{CH}_{3} \mathrm{OH}$ at $184.9 \mathrm{~nm}$ is used to estimate the FAGE sensitivity for $\mathrm{CH}_{3} \mathrm{O}$. The dominant photolysis channel of methanol between 165 and $200 \mathrm{~nm}$ generates $\mathrm{CH}_{3} \mathrm{O}$ radicals (Wen et al., 1994; Kassab et al., 1983; Marston et al., 1993):

$$
\mathrm{CH}_{3} \mathrm{OH} \stackrel{165-200 \mathrm{~nm}}{\longrightarrow} \mathrm{CH}_{3} \mathrm{O}+\mathrm{H} \text {. }
$$

A photodissociation quantum yield of $\mathrm{CH}_{3} \mathrm{O}$ of $0.86 \pm 0.10$ has been found at $193.3 \mathrm{~nm}$ (Satyapal et al., 1989) in qualitative agreement with analysis of the end-products of the methanol photodissociation at $184.9 \mathrm{~nm}$ (Porter and Noyes, 1959; Buenker et al., 1984). Here we report the first measurements of $\mathrm{CH}_{3} \mathrm{O}$ concentrations in an atmospheric simulation chamber. Methoxy radicals are generated by the $\mathrm{CH}_{3} \mathrm{O}_{2}$ selfreaction carried out within HIRAC at $295 \mathrm{~K}$ and $1000 \mathrm{mbar}$ of $\mathrm{N}_{2}$ containing $\mathrm{O}_{2}$ in trace amounts to reduce the rate of removal of $\mathrm{CH}_{3} \mathrm{O}$ by reaction with $\mathrm{O}_{2}$. This work enhances the capability of HIRAC to measure short-lived radical species by the addition of both $\mathrm{CH}_{3} \mathrm{O}_{2}$ and $\mathrm{CH}_{3} \mathrm{O}$ detection, and we discuss the potential of the method for detection of $\mathrm{CH}_{3} \mathrm{O}_{2}$ in the atmosphere itself.

\section{Experimental}

\subsection{The FAGE instrument}

Details on the HIRAC-based FAGE instrument for the detection of $\mathrm{OH}$ and $\mathrm{HO}_{2}$ has been presented previously (Winiberg et al., 2015). Figure 1 shows a schematic cross section of the instrument inlet and the two fluorescence detection cells. The gas was sampled with a flow rate of $3.2 \mathrm{slm}$ through a $1 \mathrm{~mm}$ diameter pinhole and passed down a $50 \mathrm{~mm}$ diameter flow tube of $280 \mathrm{~mm}$ length first into the $\mathrm{OH}$ detection axis and, after a further $300 \mathrm{~mm}$, into the $\mathrm{CH}_{3} \mathrm{O}_{2}$ detection axis. The pressure in the detection cells was maintained at $2.65 \pm 0.05$ Torr by using a high-capacity rotary-backed Roots blower pumping system (Leybold, Trivac D40B and Ruvac WAU251). $\mathrm{CH}_{3} \mathrm{O}_{2}$ radicals were titrated to $\mathrm{CH}_{3} \mathrm{O}$ by adding high purity NO (BOC, N2.5 nitric oxide) with a typical $2.5 \mathrm{sccm}$ flow rate (further details in Sect. 2.2) $\sim 25 \mathrm{~mm}$ before the second detection axis into the centre of the flow. The resultant $\mathrm{CH}_{3} \mathrm{O}$ radicals were measured by LIF.

Probe laser light was generated by an Nd:YAG (JDSU Q201-HD) pumped dye laser (Sirah Credo-Dye-N) using a DCM dye (Sirah) in ethanol and operating at a $5 \mathrm{kHz}$ pulse repetition frequency, with a pulse width at half maximum height of $25 \mathrm{~ns}$, typical pulse energy of $120 \mu \mathrm{J}$ pulse $^{-1}$ and a linewidth of $0.08 \mathrm{~cm}^{-1}$ at $595 \mathrm{~nm}$. The frequency doubled light at either $\sim 308 \mathrm{~nm}$ (OH detection) or $\sim 298 \mathrm{~nm}$ $\left(\mathrm{CH}_{3} \mathrm{O}\right.$ detection) was focused into fibre optic cables to be delivered to the two detection cells. $\mathrm{OH}$ and $\mathrm{CH}_{3} \mathrm{O}$ radicals were separately detected by LIF spectroscopy by exciting at $307.99 \mathrm{~nm}$ using the $\mathrm{Q}_{1}(2)$ rotational line of the $A^{2} \sum^{+}\left(v^{\prime}=\right.$ $0) \leftarrow X^{2} \Pi_{i}\left(v^{\prime \prime}=0\right) \mathrm{OH}$ transition in the first detection axis to monitor on-resonant fluorescence $(308.8 \pm 5.0 \mathrm{~nm})$ and excitation at $297.79 \mathrm{~nm}$ in the $A^{2} A_{1}\left(v_{3}^{\prime}=3\right) \leftarrow X^{2} E\left(v_{3}^{\prime \prime}=\right.$ 0) $\mathrm{CH}_{3} \mathrm{O}$ transition in the second detection axis to monitor red-shifted off-resonant LIF $(320-430 \mathrm{~nm})$. Here $v_{3}$ refers to the $\mathrm{C}-\mathrm{O}$ stretching vibrational mode of $\mathrm{CH}_{3} \mathrm{O}$ which demonstrates a progression in the LIF spectrum (Inoue et al., 1980; Kappert and Temps, 1989; Powers et al., 1997; Nagesh et al., 2014). The fluorescence in the two cells was collected orthogonal to the gas flow by two microchannel plate photomultiplier tubes (MCP-PMT) (Photek PMT325/Q/BI/G) equipped with a $50 \mathrm{~ns}$ gate unit (Photek GM10-50) for gated photon counting, and the signal was amplified using a preamplifier (Photek PA200-10). Further details on the $\mathrm{OH}$ de- 


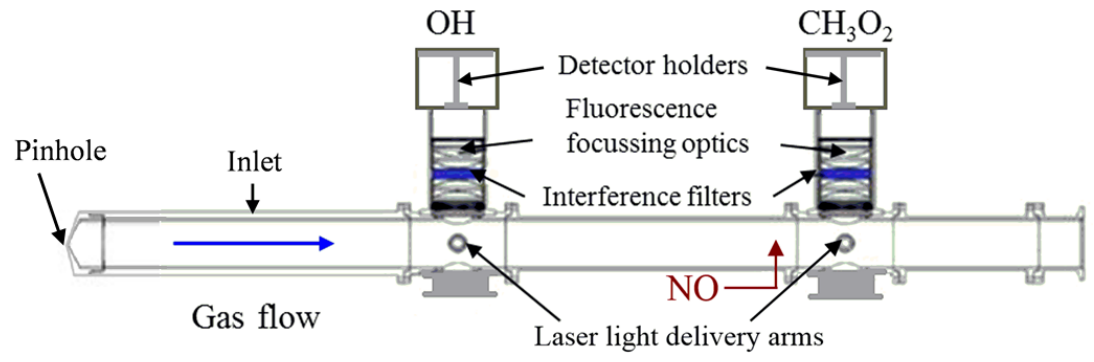

Figure 1. Vertical cross section of the FAGE fluorescence cells. The first (left) fluorescence cell was used to detect $\mathrm{OH}$ fluorescence through a $308.8 \pm 5.0 \mathrm{~nm}$ bandpass filter (transmission $>50 \%$ ) and the second cell to detect $\mathrm{CH}_{3} \mathrm{O}_{2}$ after titration with added $\mathrm{NO}$ to form $\mathrm{CH}_{3} \mathrm{O}$ using a bandpass filter between 320 and $430 \mathrm{~nm}$ with an average transmission $>80 \%$.

tection and calibration in HIRAC have been reported previously (Winiberg et al., 2015).

The laser and photon-counting timing for $\mathrm{CH}_{3} \mathrm{O}$ detection was controlled by a delay pulse generator ( 9520 series, Quantum Composers). The relatively broad bandpass filter used for the collection of the $\mathrm{CH}_{3} \mathrm{O}$ fluorescence (average transmission $>80 \%$ between 320 and $430 \mathrm{~nm}$ ) allowed some red-shifted scattered light (presumably from the walls of the chamber) generated by the probe laser to be transmitted and hence detected by the MCP-PMT. In order to ameliorate this and reduce the background signal, the gate unit was opened $100 \mathrm{~ns}$ after the laser pulse to detect fluorescence integrated over a gate width of $2 \mu \mathrm{s}$. The optimum gate width of $2 \mu$ s (values in the range 1-3 $\mu$ s were compared) is consistent with the $\mathrm{CH}_{3} \mathrm{O}$ fluorescence lifetimes, calculated to be in the range of $0.9-1.5 \mu$ s, using the reported radiative lifetimes for $\mathrm{CH}_{3} \mathrm{O}$ of $1.5 \mu$ s (Inoue et al., 1979), $2.2 \mu$ s (Ebata et al., 1982), and $4 \pm 2 \mu$ s (Wendt and Hunziker, 1979) and using the fluorescence quenching rate coefficients of $\mathrm{N}_{2}$ and $\mathrm{O}_{2}$ (Wantuck et al., 1987) to calculate the rate of quenching at the pressure in the FAGE detection cell $(2.65 \pm 0.05$ Torr). As the fluorescence lifetime of $\mathrm{CH}_{3} \mathrm{O}(A)$ in the detection cell was $0.9-1.5 \mu \mathrm{s}$, delaying the counting of the fluorescence by $100 \mathrm{~ns}$ makes very little difference $(\sim 10 \%)$ in the fraction of fluorescence collected.

All LIF signals reported here were normalized to the probe laser power as measured with a laser power meter (Maestro, Gentec-EO) before the start of each LIF measurement. Fluctuations in the relative laser power were monitored via a photodiode (UDT-555UV, Laser Components) during the measurements and were accounted for in the signal normalisation. The LIF spectrum was corrected for the laserscattered background by subtracting the normalized offline signal recorded over $60 \mathrm{~s}$ at the end of each LIF measurement using an offline wavelength $\lambda($ offline $=300.29 \mathrm{~nm})=$ $\lambda($ online $=297.79 \mathrm{~nm})+2.5 \mathrm{~nm}$, well away from any $\mathrm{CH}_{3} \mathrm{O}$ absorption. The signals were large enough that during conditions where $\mathrm{CH}_{3} \mathrm{O}_{2}$ concentrations were constant (e.g. in calibrations or during HIRAC experiments where steady-state concentrations were generated) it was established that the laser wavelength was stable over a long period once the laser wavelength had been tuned to the $\mathrm{CH}_{3} \mathrm{O}$ transition. Hence, the online wavelength position for $\mathrm{CH}_{3} \mathrm{O}$ fluorescence detection was found without using a reference cell. We are in the process of developing a reference cell for field measurements in the future, when the atmospheric concentrations of $\mathrm{CH}_{3} \mathrm{O}_{2}$ (and hence $\mathrm{CH}_{3} \mathrm{O}$ after conversion) will be both lower and more variable over short timescales. Figure 2 shows the laser excitation spectrum centred at $\sim 298 \mathrm{~nm}$ in the $\nu_{3}$ vibronic band recorded using an increment of $\Delta \lambda=10^{-3} \mathrm{~nm}$. The spectrum agrees well with previous work (Inoue et al., 1980; Kappert and Temps, 1989; Shannon et al., 2013). Figure 3 shows typical laser excitation scans performed over a narrower range of wavelengths in order to locate $\lambda$ (online). The LIF spectra were obtained by using the $\mathrm{CH}_{3} \mathrm{O}$ or $\mathrm{CH}_{3} \mathrm{O}_{2}$ radicals generated in a flow tube described in Sect. 2.3.1, with the flow-tube output impinged close to the FAGE sampling inlet. The radicals were generated using the $184.9 \mathrm{~nm}$ light output of a Hg Pen-Ray lamp by either the photolysis of methanol in nitrogen to generate $\mathrm{CH}_{3} \mathrm{O}$ or the photolysis of water vapour in synthetic air (to generate $\mathrm{OH}$ ) in the presence of methane to form $\mathrm{CH}_{3} \mathrm{O}_{2}$. The $\mathrm{CH}_{3} \mathrm{O}$ radicals were directly detected, while the $\mathrm{CH}_{3} \mathrm{O}_{2}$ radicals were first converted to $\mathrm{CH}_{3} \mathrm{O}$ species by added $\mathrm{NO}$ prior to the fluorescence detection cell (Fig. 1). Similar laser scans to the scans shown in Fig. 3 were recorded by using the $\mathrm{CH}_{3} \mathrm{O}_{2}$ radicals produced in a steady-state concentration in HIRAC using photolytic mixtures of $\mathrm{Cl}_{2}-\mathrm{CH}_{4}$-air as described in Sect. 2.3.2. There were no unexpected features in the laser scans recorded when FAGE sampled $\mathrm{CH}_{3} \mathrm{O}_{2}$ radicals from HIRAC, consistent with no interference being anticipated in the FAGE measurements of $\mathrm{CH}_{3} \mathrm{O}$ as there were no other species in HIRAC absorbing at $298 \mathrm{~nm}$ and fluorescing at the wavelengths transmitted by the bandpass filter (average transmission $>80 \%$ over $320-430 \mathrm{~nm}$ ).

\subsection{Optimisation of the NO concentration for methyl peroxy radical detection}

As $\mathrm{NO}$ was added $\sim 25 \mathrm{~mm}$ prior the methoxy detection axis (Fig. 1), some of the methoxy radicals formed by Re- 


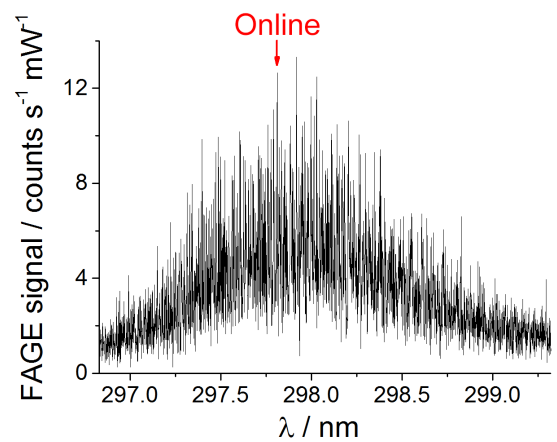

Figure 2. Laser excitation spectrum of the $A^{2} A_{1}\left(v_{3}^{\prime}=3\right) \leftarrow X^{2} E$ $\left(v_{3}^{\prime \prime}=0\right)$ transition of the methoxy radical. $\mathrm{CH}_{3} \mathrm{O}$ radicals were obtained by photolysis of methanol in $\mathrm{N}_{2}$ at $184.9 \mathrm{~nm}$. Fluorescence cell pressure $=2.65 \pm 0.05$ Torr; wavelength increment $\Delta \lambda=10^{-3} \mathrm{~nm}$, with each point corresponding to 5000 laser shots. The red arrow indicates the wavelength $\lambda$ (online) $\sim 297.79 \mathrm{~nm}$ used for the time-resolved kinetic studies of $\mathrm{CH}_{3} \mathrm{O}_{2}$.

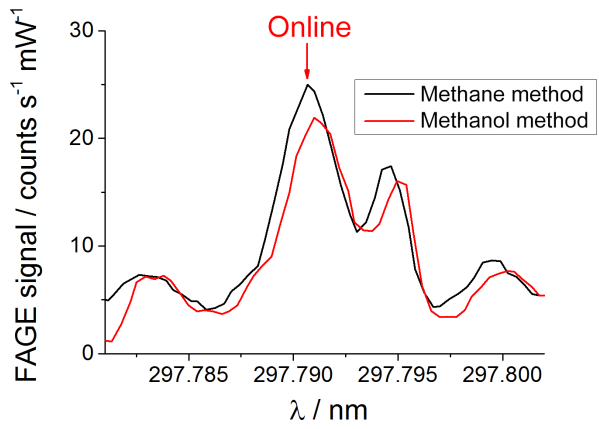

Figure 3. Typical laser excitation scans of $\mathrm{CH}_{3} \mathrm{O}$ performed over a much smaller range of wavelengths. Methoxy radicals were generated using $\mathrm{OH}$ and $\mathrm{CH}_{4}$ (black line) to produce $5.5 \times 10^{10}$ molecule $\mathrm{cm}^{-3} \mathrm{CH}_{3} \mathrm{O}_{2}$, subsequently titrated to $\mathrm{CH}_{3} \mathrm{O}$ by adding $\mathrm{NO}$, and the photolysis of methanol (red line) to generate $4.9 \times 10^{10}$ molecule $\mathrm{cm}^{-3} \mathrm{CH}_{3} \mathrm{O}$ directly. See main text for the description of the methods and calibration. The signal was normalised for the laser power $(10.3 \pm 0.3 \mathrm{~mW}$ in the methane method and $8.7 \pm 0.2 \mathrm{~mW}$ in the methanol method). Fluorescence cell pressure $=2.65 \pm 0.05$ Torr; wavelength increment $\Delta \lambda=10^{-3} \mathrm{~nm}$, with each point corresponding to 5000 laser shots. The red arrow indicates the wavelength $\lambda$ (online) $\sim 297.79 \mathrm{~nm}$ used for the timeresolved kinetic studies of $\mathrm{CH}_{3} \mathrm{O}_{2}$.

action (R3) reacted further with NO before the fluorescence detection:

$$
\begin{aligned}
& \mathrm{CH}_{3} \mathrm{O}+\mathrm{NO} \rightarrow \mathrm{CH}_{2} \mathrm{O}+\mathrm{HNO}, \\
& \mathrm{CH}_{3} \mathrm{O}+\mathrm{NO}+\mathrm{M} \rightarrow \mathrm{CH}_{3} \mathrm{ONO}+\mathrm{M},
\end{aligned}
$$

where $\mathrm{M}=\mathrm{N}_{2}, \mathrm{O}_{2}$. In addition to the above reactions, $\mathrm{CH}_{3} \mathrm{O}$ reacts with $\mathrm{O}_{2}$ by Reaction (R4). Figure 4 shows the dependence of the LIF signal on the concentration of NO obtained experimentally and by numerical simulations using Reactions (R3)-(R4) and (R10)-(R11) and outlined in the Supplement. A maximum signal was obtained with

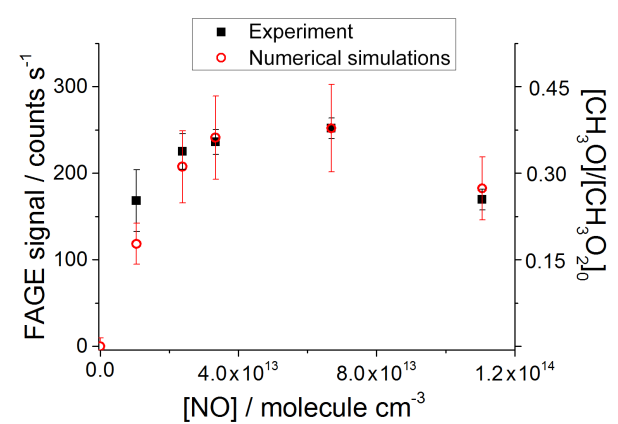

Figure 4. FAGE signal (left axis) and the ratio $\left[\mathrm{CH}_{3} \mathrm{O}\right] /\left[\mathrm{CH}_{3} \mathrm{O}_{2}\right]_{0}$ (right axis) as a function of the concentration of $\mathrm{NO}$ for a reaction time of $3 \mathrm{~ms}$. Black squares are experimental $\mathrm{CH}_{3} \mathrm{O}$ signals (errors are $1 \sigma)$ and red circles are the ratio $\left[\mathrm{CH}_{3} \mathrm{O}\right] /\left[\mathrm{CH}_{3} \mathrm{O}_{2}\right]_{0}$ generated by numerical simulations (percentage uncertainties are $20 \%$ ) using the chemistry system outlined in the main text and described in further detail in the Supplement.

added $[\mathrm{NO}]=6.7 \times 10^{13}$ molecule $\mathrm{cm}^{-3}$ for a reaction time of $3 \mathrm{~ms}$, estimated from the linear flow velocity within the FAGE reactor. Figure 4 shows that the functional dependence with added [NO] of the experimental $\mathrm{CH}_{3} \mathrm{O}$ signal and the simulated $\left[\mathrm{CH}_{3} \mathrm{O}\right] /\left[\mathrm{CH}_{3} \mathrm{O}_{2}\right]_{0}$ ratio display the same shape (within overlapping error limits), with the numerical simulations showing that $\left[\mathrm{CH}_{3} \mathrm{O}\right] /\left[\mathrm{CH}_{3} \mathrm{O}_{2}\right]_{0}$ at the detection axis was $\sim 0.4$ (i.e. $40 \%$ conversion to $\mathrm{CH}_{3} \mathrm{O}$ ).

\subsection{FAGE calibrations}

$\mathrm{CH}_{3} \mathrm{O}$ and $\mathrm{CH}_{3} \mathrm{O}_{2}$ calibrations were carried out using the conventional radical source, employed in fieldwork for $\mathrm{OH}$ and $\mathrm{HO}_{2}$ calibrations (Heard and Pilling, 2003), that produces radicals in a flow tube impinging just outside the FAGE inlet pinhole (Winiberg et al., 2015) and is described in Sect. 2.3.1. Two methods of calibration have been used for $\mathrm{CH}_{3} \mathrm{O}_{2}$ : the flow-tube method and the kinetics of the selfreaction of $\mathrm{CH}_{3} \mathrm{O}_{2}$ carried out in HIRAC.

\subsubsection{Calibration for methoxy radicals}

In the $\mathrm{CH}_{3} \mathrm{O}$ calibration experiments, nitrogen (BOC, $>99.998 \%$ ) was used as carrier gas. Part of the $\mathrm{N}_{2}$ flow was passed through a methanol (Sigma Aldrich, $\geq 99.9 \%$ ) bubbler while the other portion bypassed the bubbler. The gas containing methanol vapour was then passed through a square-cross-section flow tube of dimensions $13 \times 13 \mathrm{~mm}$ (internal) and $300 \mathrm{~mm}$ length with a flow rate of $40 \mathrm{slm}$ (ensuring turbulent flow conditions), controlled by an electronic flow controller (Brooks, 0-100 slm air). The collimated light of a $\mathrm{Hg}$ Pen-Ray lamp (LOT-Oriel, $\mathrm{Hg}(\mathrm{Ar})$ ) was directed across the flow tube (close to the downstream end) to photolyse methanol vapour. The flow-tube output was impinged close to the FAGE inlet to sample $\mathrm{CH}_{3} \mathrm{O}$ radicals at atmospheric pressure through a $1 \mathrm{~mm}$ diameter pinhole (Fig. 1). 
The concentration of $\mathrm{CH}_{3} \mathrm{O}$ radicals was calculated using Eq. (1):

$$
\begin{aligned}
{\left[\mathrm{CH}_{3} \mathrm{O}\right]=} & {\left[\mathrm{CH}_{3} \mathrm{OH}\right] \sigma_{\mathrm{CH}_{3} \mathrm{OH}, 184.9 \mathrm{~nm}} } \\
& \Phi_{\mathrm{CH}_{3} \mathrm{O}}, 184.9 \mathrm{~nm} F_{184.9 \mathrm{~nm}} \Delta t,
\end{aligned}
$$

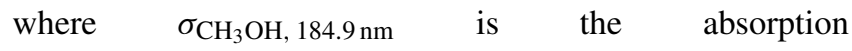
cross section of methanol at $184.9 \mathrm{~nm}$, $(6.35 \pm 0.28) \times 10^{-19} \mathrm{~cm}^{2}$ molecule ${ }^{-1}$, obtained by averaging reported values (Dillon et al., 2005; Jimenez et al., 2003; Nee et al., 1985); $F_{184.9 \mathrm{~nm}}$ is the photon flux of $184.9 \mathrm{~nm}$ light; and $\Delta t$ is the irradiation time of the gas. Although it is known, based on end-product analysis, that the scission of the $\mathrm{O}-\mathrm{H}$ bond is a major photolysis channel of methanol at $184.9 \mathrm{~nm}$ (Buenker et al., 1984; Porter and Noyes, 1959), the photodissociation quantum

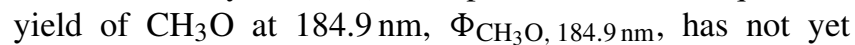
been reported. Here it is assumed that $\Phi_{\mathrm{CH}_{3} \mathrm{O}, 184.9 \mathrm{~nm}}$ is equal to the photodissociation quantum yield at $193.3 \mathrm{~nm}$, $\Phi_{\mathrm{CH}_{3} \mathrm{O}, 193.3 \mathrm{~nm}}=0.86 \pm 0.10$, which has been reported (Satyapal et al., 1989). In order to determine the methanol vapour concentration in the flow tube, $\left[\mathrm{CH}_{3} \mathrm{OH}\right]$, separate experiments were carried out with the same calibration system to bubble deionised water instead of methanol with the same flow rate. The water vapour concentration, $\left[\mathrm{H}_{2} \mathrm{O}\right]$, was measured using a dew-point hygrometer (CR4, Buck Research Instruments) prior to the flow tube. Then $\left[\mathrm{CH}_{3} \mathrm{OH}\right]$ was calculated using the averaged $\left[\mathrm{H}_{2} \mathrm{O}\right]$ and the vapour pressures $p_{\mathrm{CH}_{3} \mathrm{OH}}$ and $p_{\mathrm{H}_{2} \mathrm{O}}$ at the temperatures measured for $\mathrm{CH}_{3} \mathrm{OH}\left(13^{\circ} \mathrm{C}\right)$ and $\mathrm{H}_{2} \mathrm{O}\left(15^{\circ} \mathrm{C}\right)$ in the bubbler:

$$
\left[\mathrm{CH}_{3} \mathrm{OH}\right]=\left[\mathrm{H}_{2} \mathrm{O}\right] \frac{p_{\mathrm{CH}_{3} \mathrm{OH}}}{p_{\mathrm{H}_{2} \mathrm{O}}} .
$$

Equation (2) assumes that there were no losses of water vapour and methanol vapour by condensation in the tubing connecting the bubbler to the flow tube. This is as expected based on the small difference in temperature between the bubbler (vide supra) and the connecting tubing (typically held at $\sim 20^{\circ} \mathrm{C}$ ) and as the gas going through the bubbler was diluted with the gas bypassing the bubbler.

$\mathrm{N}_{2} \mathrm{O}$ photolysis at $184.9 \mathrm{~nm}$ to generate $\mathrm{NO}$ (via reaction of the photoproduct $\left(\mathrm{O}^{1} \mathrm{D}\right)$ with $\mathrm{N}_{2} \mathrm{O}$ giving a known yield of NO), which was subsequently measured using a commercial analyser, was used as a chemical actinometer to obtain the product $F_{184.9 \mathrm{~nm}} \times \Delta t$ (Winiberg et al., 2015) and hence calculate $\left[\mathrm{CH}_{3} \mathrm{O}\right]$ via Eq. (1). The photolysis time, $\Delta t$, was estimated to be $8.3 \mathrm{~ms}$, using the volumetric flow rate and the geometric parameters of the flow tube (assuming plug flow), and was in turn used to determine $F_{184.9} \mathrm{~nm}$. Although it is the product $F_{184.9 \mathrm{~nm}} \times \Delta t$ which is used to calculate $\left[\mathrm{CH}_{3} \mathrm{O}\right]$, any change in the volumetric flow rate between the calibration and actinometry experiments will change $\Delta t$, and hence the product was corrected for any changes in volumetric flow rate. A range of $\left[\mathrm{CH}_{3} \mathrm{O}\right]$ at constant $\left[\mathrm{CH}_{3} \mathrm{OH}\right]$ was produced by changing the electrical current through the Hg lamp be- tween 0 and $20 \mathrm{~mA}$, and hence $F_{184.9 \mathrm{~nm}}$, to generate the calibration plot presented in Fig. 5.

\subsubsection{Calibration for methyl peroxy radicals}

\section{Flow-tube method}

Methyl peroxy radicals were generated by water photolysis at $184.9 \mathrm{~nm}$ (Reaction R7) to give $\mathrm{OH}$, followed by the reaction with excess methane in air (BOC, synthetic BTCA 178) - Reactions (R1)-(R2) to give $\mathrm{CH}_{3} \mathrm{O}_{2}$. The calibrations were performed using the set-up described above. Methane (BOC, CP grade, $99.5 \%$ ) was flowed at $82.5 \mathrm{sccm}$ to convert $\mathrm{OH}$ into $\mathrm{CH}_{3}$, which subsequently reacted rapidly with $\mathrm{O}_{2}$ to form $\mathrm{CH}_{3} \mathrm{O}_{2}$. Figure $\mathrm{S} 1$ (Supplement) shows an example of the $\mathrm{OH}$ signal with and without $\mathrm{CH}_{4}$. The signal in the presence of $\mathrm{CH}_{4}$ was $0.04 \pm 0.04$ of the signal in the absence of $\mathrm{CH}_{4}$ showing that $0.96 \pm 0.04$ of $\mathrm{OH}$ was converted into $\mathrm{CH}_{3} \mathrm{O}_{2}$. The result is in agreement with the estimation of the fraction of $\mathrm{OH}$ titrated to $\mathrm{CH}_{3} \mathrm{O}_{2}, 0.97$, using a rate coefficient of $6.4 \times 10^{-15} \mathrm{~cm}^{3}$ molecule $\mathrm{e}^{-1} \mathrm{~s}^{-1}$ for the $\mathrm{OH}+\mathrm{CH}_{4}$ reaction (Atkinson et al., 2006) and an average residence time of $\mathrm{OH}$ in the calibration flow tube of $11 \mathrm{~ms}$ determined using the volumetric flow rate and the geometric parameters of the flow tube and position of the $\mathrm{Hg}$ pen lamp.

The concentration of $\mathrm{CH}_{3} \mathrm{O}_{2}$ was determined using Eq. (3):

$$
\begin{aligned}
{\left[\mathrm{CH}_{3} \mathrm{O}_{2}\right]=} & 0.96[\mathrm{OH}]=0.96\left[\mathrm{H}_{2} \mathrm{O}\right] \sigma_{\mathrm{H}_{2} \mathrm{O}}, 184.9 \mathrm{~nm} \\
& \Phi_{\mathrm{H}_{2} \mathrm{O}}, 184.9 \mathrm{~nm} F_{184.9 \mathrm{~nm}} \Delta t,
\end{aligned}
$$

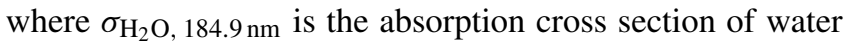
vapour at $184.9 \mathrm{~nm},(7.22 \pm 0.22) \times 10^{-20} \mathrm{~cm}^{2}$ molecule $^{-1}$ (Cantrell et al., 1997; Creasey et al., 2000), and $\Phi_{\mathrm{H}_{2} \mathrm{O}}, 184.9 \mathrm{~nm}$ is the photodissociation quantum yield of $\mathrm{OH}$, which is equal to unity. The values of $F_{184.9 \mathrm{~nm}}$ and $\Delta t$ were determined as described in the Sect. 2.3.1. No loss of $\mathrm{CH}_{3} \mathrm{O}_{2}$ by reaction with the $\mathrm{HO}_{2}$ radicals generated by the reaction of $\mathrm{H}$ atoms with $\mathrm{O}_{2}$ (Reaction R8) was encountered over the residence time of the radicals in the calibration flow tube $(\sim 11 \mathrm{~ms})$ as $\mathrm{CH}_{3} \mathrm{O}_{2}$ reacts with $\mathrm{HO}_{2}$ on a $10 \mathrm{~s}$ timescale as determined using a reaction rate coefficient of $5.2 \times 10^{-12} \mathrm{~cm}^{3}$ molecule ${ }^{-1} \mathrm{~s}^{-1}$ (Atkinson et al., 2006) and the radical concentrations in the flow tube. The $\mathrm{CH}_{3} \mathrm{O}_{2}$ radicals sampled through the FAGE pinhole expansion to a pressure of 2.65 Torr reached the detection region in about $85 \mathrm{~ms}$, while the calculated $\mathrm{CH}_{3} \mathrm{O}_{2}+\mathrm{HO}_{2}$ reaction half-life at this reduced pressure in the FAGE inlet was thousands of seconds, and any change in the $\mathrm{CH}_{3} \mathrm{O}_{2}$ concentration is expected to be negligible.

Figure 6 shows results obtained from three separate calibration experiments. In the first two experiments air was humidified by passing a fraction of the air flow $(40 \mathrm{slm}$ total flow rate) through a deionised water bubbler. The hygrometer measured $7.5 \times 10^{16}$ molecule $\mathrm{cm}^{-3}$ of water vapour prior to the calibration flow tube, and the concentration of methane 


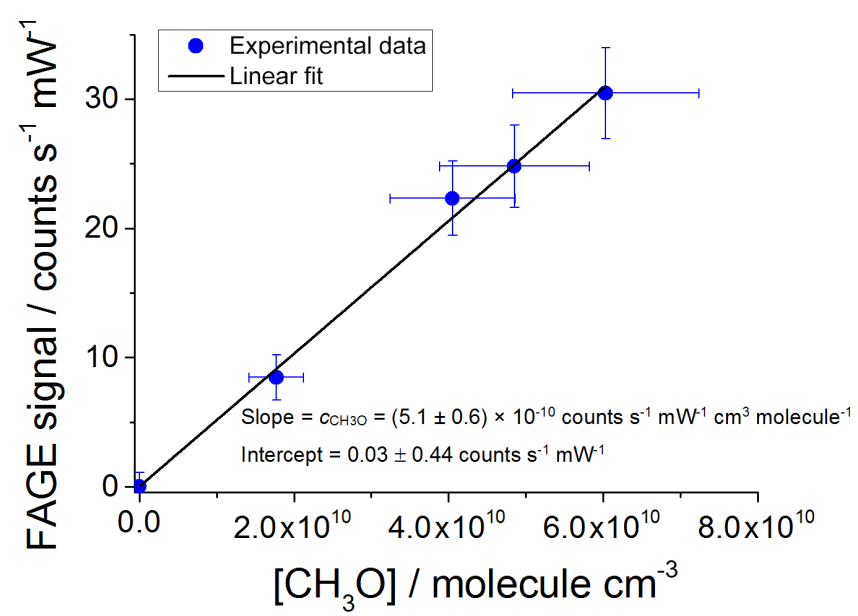

Figure 5. FAGE calibration for $\mathrm{CH}_{3} \mathrm{O}$ at atmospheric pressure and $293 \mathrm{~K}$; laser power $P=12.9 \pm 0.3 \mathrm{~mW}$ and pressure in the detection cell is $2.65 \pm 0.05$ Torr. The FAGE signal, including the measurement with the $\mathrm{Hg}$ lamp turned off $\left(\left[\mathrm{CH}_{3} \mathrm{O}\right]=0\right)$, was obtained after subtraction of the offline signal, $12.3 \pm 0.9$ counts s ${ }^{-1} \mathrm{~mW}^{-1}$. Averaging time per point $=120 \mathrm{~s}$. The error limits in $\left[\mathrm{CH}_{3} \mathrm{O}\right]$ and the FAGE signal for the $x$ and $y$ axes respectively are representative of the $1 \sigma$ overall uncertainty, which contains the total systematic and statistical errors (see text for details of these). The error limits shown in the legend are the standard errors in the slope and intercept of the fit to the experimental data.

in the flow tube was $5 \times 10^{16}$ molecule $\mathrm{cm}^{-3}$. In the second experiment, a series of FAGE measurements were performed using a photon flux of $\sim 1.6 \times 10^{14}$ photon $\mathrm{cm}^{-2} \mathrm{~s}^{-1}$ to generate $\sim 4.5 \times 10^{9}$ molecule $\mathrm{cm}^{-3} \mathrm{CH}_{3} \mathrm{O}_{2}$. In the third experiment $\left[\mathrm{CH}_{4}\right]=10^{17}$ molecule $\mathrm{cm}^{-3}$ and all the air flow (now at $20 \mathrm{slm}$ ) was passed through the water bubbler to obtain $3 \times 10^{17}$ molecule $\mathrm{cm}^{-3} \mathrm{H}_{2} \mathrm{O}$ vapour. The concentration of $\mathrm{CH}_{3} \mathrm{O}_{2}$ was varied by changing the photon flux in the range of $0.5-1.5 \times 10^{14}$ photon $\mathrm{cm}^{-2} \mathrm{~s}^{-1}$ to generate $\left[\mathrm{CH}_{3} \mathrm{O}_{2}\right]=1.5-4.5 \times 10^{10}$ molecule $\mathrm{cm}^{-3}$.

\section{$\mathrm{CH}_{3} \mathrm{O}_{2}$ second-order decay method}

The principle behind this calibration method is that the second-order decay of $\mathrm{CH}_{3} \mathrm{O}_{2}$ is dependent upon its initial concentration, and hence its quantification offers an alternative way to calibrate the signal. The experiments were performed in the HIRAC chamber at $295 \mathrm{~K}$ and 1 bar of synthetic air obtained by mixing high purity oxygen $(\mathrm{BOC},>99.999 \%)$ and nitrogen $(\mathrm{BOC},>99.998 \%)$ in the ratio of $\mathrm{O}_{2}: \mathrm{N}_{2}=1: 4$. Methane (BOC, CP grade, $2-3 \times 10^{17}$ molecule $\mathrm{cm}^{-3}$ ) and molecular chlorine (Sigma Aldrich, $\geq 99.5 \%, 0.3-2.1 \times 10^{14}$ molecule $\mathrm{cm}^{-3}$ ) were delivered to the chamber. Eight UV black lamps (Phillips, TL-D 36W/BLB, $\lambda=350-400 \mathrm{~nm}$ ) housed in quartz tubes mounted radially inside the reactive volume were used to photolyse $\mathrm{Cl}_{2}$ to generate $\mathrm{Cl}$ atoms and initiate the chem-

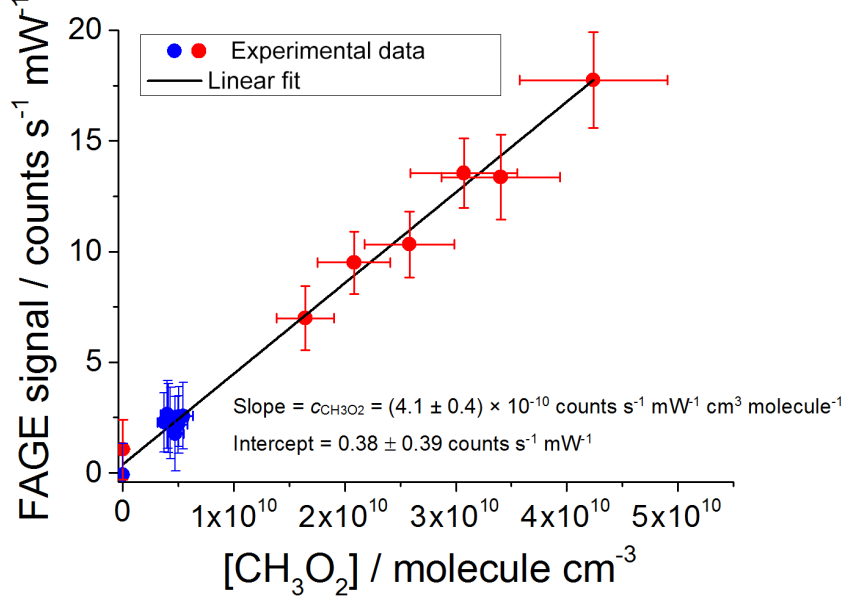

Figure 6. FAGE calibration for $\mathrm{CH}_{3} \mathrm{O}_{2}$ at atmospheric pressure and $293 \mathrm{~K}$. The data were obtained by three separate experiments: two of them generating $\left[\mathrm{CH}_{3} \mathrm{O}_{2}\right] \cong 4.5 \times 10^{9}$ molecule $\mathrm{cm}^{-3}$ in the calibration flow tube (blue circles); laser power $P=9.5 \pm$ $0.3 \mathrm{~mW}$ and $11.6 \pm 0.4 \mathrm{~mW}$ respectively and one experiment using $\left[\mathrm{CH}_{3} \mathrm{O}_{2}\right]$ in the range of $1.5-4.5 \times 10^{10}$ molecule $\mathrm{cm}^{-3}$ (red circles); $P=9.2 \pm 0.2 \mathrm{~mW}$. The pressure in the FAGE detection cell was maintained at $2.65 \pm 0.05$ Torr in all experiments. Averaging time per point $=120 \mathrm{~s}$. The error limits in $\left[\mathrm{CH}_{3} \mathrm{O}_{2}\right]$ and the FAGE signal for the $x$ and $y$ axes respectively are representative for the $1 \sigma$ overall uncertainty, which contains the total systematic and statistical errors. The error limits shown in the legend are the standard errors in the slope and intercept of the fit to the experimental data.

istry:

$\mathrm{CH}_{4}+\mathrm{Cl} \rightarrow \mathrm{CH}_{3}+\mathrm{HCl}$,
$\mathrm{CH}_{3}+\mathrm{O}_{2}+\mathrm{M} \rightarrow \mathrm{CH}_{3} \mathrm{O}_{2}+\mathrm{M}$.

Numerical simulations using the chemical system described in Table $\mathrm{S} 3$ in the Supplement showed that $[\mathrm{Cl}]_{0}=1-$ $6 \times 10^{6}$ molecule $\mathrm{cm}^{-3}$ (varied by changing the initial $\left[\mathrm{Cl}_{2}\right]$ ). The high excess of methane $\left(2-3 \times 10^{17}\right.$ molecule $\left.\mathrm{cm}^{-3}\right)$ relative to $[\mathrm{Cl}]_{0}$ ensured that the reactions of the $\mathrm{Cl}$ atoms with the self-reaction products formaldehyde and methanol were negligible. In each HIRAC experiment the lamps were alternatively turned on for 2-3 min and then off over 1-2 min to generate a series of typically $3-4 \mathrm{CH}_{3} \mathrm{O}_{2}$ kinetic decays.

In order to detect $\mathrm{CH}_{3} \mathrm{O}_{2}$ the FAGE instrument was coupled to HIRAC through a custom-made ISO-K160 flange to sample the gas with a flow rate of $\sim 3 \mathrm{slm}$. For most measurements, the $1 \mathrm{~mm}$ pinhole of the $280 \mathrm{~mm}$ long FAGE inlet sampled $\sim 230 \mathrm{~mm}$ from the chamber wall as in the $\mathrm{OH}$ measurements reported previously (Winiberg et al., 2015). Additional investigations into any $\mathrm{CH}_{3} \mathrm{O}_{2}$ gradient across the $\sim 600 \mathrm{~mm}$ radius of HIRAC were conducted using measurements of $\mathrm{CH}_{3} \mathrm{O}_{2}$ formed by the $\mathrm{CH}_{4}$ reaction with $\mathrm{O}^{1} \mathrm{D}$ generated by the photolysis of $\mathrm{O}_{3}$ at $254 \mathrm{~nm}$ followed by the reaction of the produced $\mathrm{CH}_{3}$ radical with $\mathrm{O}_{2}$ at $295 \mathrm{~K}$ and 1 bar of synthetic air. An extended FAGE inlet (length 
$520 \mathrm{~mm}$ ) was used to sample along $500 \mathrm{~mm}$ across the chamber starting with the inlet pinhole flush at the wall. A constant concentration of $\mathrm{CH}_{3} \mathrm{O}_{2}$ was found (within the $10 \%$ overall error of the measurement) for all the sampled distances of $0-500 \mathrm{~mm}$ from the wall (note that $0 \mathrm{~mm}$ here refers to the FAGE inlet being at an equivalent position to the wall away from the mounting flange). The absence of a $\mathrm{CH}_{3} \mathrm{O}_{2}$ gradient across the chamber provides evidence of the efficacy of the mixing in HIRAC and shows that the wall loss of $\mathrm{CH}_{3} \mathrm{O}_{2}$ is negligible and hence that a shorter inlet, and hence distance from inlet to $\mathrm{CH}_{3} \mathrm{O}_{2}$ detection axis, could be used in future $\mathrm{CH}_{3} \mathrm{O}_{2}$ FAGE measurements within HIRAC, improving further the sensitivity.

\subsection{Methoxy radical measurements within HIRAC}

The experiment was carried out in HIRAC at $295 \mathrm{~K}$ and 1 bar of $\mathrm{N}_{2}$ (BOC, $>99.998 \%$ ), but without any NO added to the FAGE cell (the cell furthest from the pinhole as shown in Fig. 1) so that $\left[\mathrm{CH}_{3} \mathrm{O}\right]$ is measured directly. Initial concentrations in HIRAC were $\left[\mathrm{CH}_{4}\right]_{0}=4.50 \times 10^{17}$ molecule $\mathrm{cm}^{-3}$ and $\left[\mathrm{Cl}_{2}\right]_{0}=5.57 \times 10^{15}$ molecule $\mathrm{cm}^{-3}$. After adding the reagents into the chamber, the lamps (vide supra) were turned on to generate $\mathrm{CH}_{3} \mathrm{O}$ by Reaction (R6b).

\section{Results}

\subsection{Sensitivity and detection limits for $\mathrm{CH}_{3} \mathrm{O}_{2}$ and $\mathrm{CH}_{3} \mathrm{O}$ radicals obtained from calibrations}

\subsubsection{Flow-tube method}

The FAGE sensitivity for $\mathrm{CH}_{3} \mathrm{O}_{2} \quad\left(\mathrm{C}_{\mathrm{CH}_{3} \mathrm{O}_{2}}\right)$ and $\mathrm{CH}_{3} \mathrm{O}$ $\left(C_{\mathrm{CH}_{3} \mathrm{O}}\right)$ is the slope of the linear regressions in Figs. 5 and 6 , which were $C_{\mathrm{CH}_{3} \mathrm{O}_{2}}=(4.1 \pm 1.4) \times$ $10^{-10}$ counts $\mathrm{cm}^{3}$ molecule ${ }^{-1} \mathrm{~s}^{-1} \mathrm{~mW}^{-1}$ and $C_{\mathrm{CH}_{3} \mathrm{O}}=$ $(5.1 \pm 2.2) \times 10^{-10}$ counts $\mathrm{cm}^{3}$ molecule $\mathrm{s}^{-1} \mathrm{~s}^{-1} \mathrm{~mW}^{-1}$. The error limits, $34 \%$ for $C_{\mathrm{CH}_{3} \mathrm{O}_{2}}$ and $43 \%$ for $C_{\mathrm{CH}_{3} \mathrm{O}}$, are the overall $2 \sigma$ uncertainties calculated using the sum in quadrature of the systematic uncertainties, $33 \%$ for $\mathrm{CH}_{3} \mathrm{O}_{2}$ and $42 \%$ for $\mathrm{CH}_{3} \mathrm{O}$ (details in Sect. 3.2.1), and the statistical errors from the calibration plots, $\sim 8 \%$. The higher errors in $C_{\mathrm{CH}_{3} \mathrm{O}}$ compared to $C_{\mathrm{CH}_{3} \mathrm{O}_{2}}$ are due to the uncertainty in the methanol concentration, which is not determined directly (vide supra), and the error in the yield of $\mathrm{CH}_{3} \mathrm{O}$ from $\mathrm{CH}_{3} \mathrm{OH}$ photolysis. The value of the $\mathrm{CH}_{3} \mathrm{O}$ photolysis yield from $\mathrm{CH}_{3} \mathrm{OH}$ reported at $193 \mathrm{~nm}$ was used $(0.86 \pm 0.10)$, which has an uncertainty of $12 \%$ at the $1 \sigma$ level (Satyapal et al., 1989).

From the sensitivity factor, $C$, the limit of detection (LOD) was calculated using Eq. (4) and assuming Poisson statistics appropriate for single photon counting:

$$
\begin{aligned}
& \mathrm{LOD}\left(\mathrm{CH}_{3} \mathrm{O}_{2}\right)=\frac{S / N}{C_{\mathrm{CH}_{3} \mathrm{O}_{2}} P} \sqrt{\frac{\mathrm{BKG}}{t}\left(\frac{1}{m}+\frac{1}{n}\right)}, \\
& \mathrm{LOD}\left(\mathrm{CH}_{3} \mathrm{O}\right)=\frac{S / N}{C_{\mathrm{CH}_{3} \mathrm{O}} P} \sqrt{\frac{\mathrm{BKG}}{t}\left(\frac{1}{m}+\frac{1}{n}\right)},
\end{aligned}
$$

where $S / N$ is the signal-to-noise ratio; $P$ is the laser power; $\mathrm{BKG}$ is the background signal and had a typical value of $\sim 100$ counts $\mathrm{s}^{-1}$, which represents $\sim 50$ counts $\mathrm{s}^{-1}$ laserscattered light within the detection cell and $\sim 50$ counts $\mathrm{s}^{-1}$ scattered visible light which enters the pinhole from the room with a negligible contribution $\left(1\right.$ count $^{-1}$ on average) of the detector dark counts; $t$ is the time per data point; $m$ represents the number of online data points; and $n$ is the number of offline data points. For a typical $5 \mathrm{~min}$ averaged signal, i.e. $m=n=150, S / N=2$, $P=15 \mathrm{~mW}$ and $t=1 \mathrm{~s}$, and using the values of $C$ from the calibration, $\operatorname{LOD}\left(\mathrm{CH}_{3} \mathrm{O}_{2}\right)=3.8 \times 10^{8}$ molecule $\mathrm{cm}^{-3}$ and $\operatorname{LOD}\left(\mathrm{CH}_{3} \mathrm{O}\right)=3.0 \times 10^{8}$ molecule $\mathrm{cm}^{-3}$. An increase in the averaging time to $1 \mathrm{~h}$, i.e. $m=n=1800$ data points, results in a decrease in the detection limits to $\mathrm{LOD}\left(\mathrm{CH}_{3} \mathrm{O}_{2}\right)=1.1 \times 10^{8}$ molecule $\mathrm{cm}^{-3}$ and $\mathrm{LOD}\left(\mathrm{CH}_{3} \mathrm{O}\right)=8.7 \times 10^{7}$ molecule $\mathrm{cm}^{-3}$.

Although $\mathrm{CH}_{3} \mathrm{O}_{2}$ has not been measured specifically in the atmosphere, there have been several calculations of its concentration using numerical models. In general, the concentration of $\mathrm{CH}_{3} \mathrm{O}_{2}$ is a function of both the loadings of VOCs and the levels of $\mathrm{NO}_{x}$. For the clean, remote environments at Cape Verde in the tropical Atlantic Ocean and in the Borneo rainforest, $\left[\mathrm{CH}_{3} \mathrm{O}_{2}\right]$ is calculated to peak around $6 \times 10^{8}$ molecule $\mathrm{cm}^{-3}$ and about $2 \times 10^{8}$ molecule $\mathrm{cm}^{-3}$ respectively at noon using the modelling studies reported by Whalley et al. (2010, 2011). Therefore, it should be possible using the FAGE conversion method for $\mathrm{CH}_{3} \mathrm{O}_{2}$ with an averaging time of $1 \mathrm{~h}$ (vide supra) to achieve a measurement of atmospheric levels of $\mathrm{CH}_{3} \mathrm{O}_{2}$ in such clean environments, and shorter averaging times in some cases. Further optimisations of FAGE sensitivity can be achieved by the removal of the fibre optic cables to deliver the probe laser beam directly to the $\mathrm{CH}_{3} \mathrm{O}$ detection cell to increase the laser power and by increasing the pulse repetition frequency above the current value of $5 \mathrm{kHz}$ (but without significant reduction in the pulse energy). The present investigations into the change of sensitivity with pressure in the range from 2.65 to 10.00 Torr found that 2.65 Torr is the optimum value in this pressure interval. The result suggests that, by reducing the pressure in the above range of values, the decrease in fluorescence due to the reduction in the $\mathrm{CH}_{3} \mathrm{O}$ number density was overcome by the increase in the fluorescence quantum yield due to a lower fluorescence quenching rate. Another reason could be that the characteristics of the jet expansion and/or the ensuing flow to the LIF detection region change with pressure, leading to a more favourable transmission of radicals to the 
detection region, but it is difficult to test this experimentally. Hence an additional improvement in the sensitivity might be obtained by using a lower detection cell pressure than the current value of 2.65 Torr using a more powerful pump. It should be also noted that the distance from the inlet pinhole to the laser axis in the $\mathrm{CH}_{3} \mathrm{O}$ and $\mathrm{CH}_{3} \mathrm{O}_{2}$ fluorescence cell (Fig. 1, $\sim 580 \mathrm{~mm}$ ) is considerably longer than the corresponding distance in the ground-based field fluorescence cell for $\mathrm{OH}$ and $\mathrm{HO}_{2}$ detection $(88 \mathrm{~mm})$, and improvements in sensitivity would be expected for a shorter pinhole-to-laser excitation distance for $\mathrm{CH}_{3} \mathrm{O}_{2}$. The further optimisations of sensitivity and the planned construction of a reference cell to find the online wavelength position could potentially enable $\mathrm{CH}_{3} \mathrm{O}_{2}$ measurements to be made in urban environments where $\mathrm{CH}_{3} \mathrm{O}_{2}$ concentrations are estimated to be considerably lower - for example a few $10^{7}$ molecule $\mathrm{cm}^{-3}$ based on modelling results (Whalley et al., 2017).

The calibrations using the flow-tube ("wand") method have been performed under water vapour concentrations similar to the ambient $\left[\mathrm{H}_{2} \mathrm{O}_{\text {vapour }}\right]$ but a few orders of magnitude higher than those present in the HIRAC chamber experiments. In contrast with $\left[\mathrm{H}_{2} \mathrm{O}_{\text {vapour }}\right]$, the methane concentrations used in the "wand" method were similar to $\left[\mathrm{CH}_{4}\right]$ present in HIRAC but higher than $\left[\mathrm{CH}_{4}\right]$ in the atmosphere. However, as detailed in this paragraph, the effects of methane and water vapour on our sensitivity are minimal. Estimations using the reported fluorescence quenching rate coefficient of $\mathrm{CH}_{3} \mathrm{O}(A)$ by $\mathrm{CH}_{4}$, $k_{\text {quench. } \mathrm{CH}_{4}}=1.05 \times 10^{-10} \mathrm{~cm}^{3}$ molecule ${ }^{-1} \mathrm{~s}^{-1}$, (Wantuck et al., 1987) and the concentrations of $\mathrm{CH}_{4}$ in the LIF detection cell for the calibrations using the flow tube $\left(1.7 \times 10^{14}\right.$ and $3.4 \times 10^{14}$ molecule $\mathrm{cm}^{-3}$, corresponding to $5.0 \times 10^{16}$ and $1.0 \times 10^{17}$ molecule $\mathrm{cm}^{-3}$ respectively in the flow tube) resulted in only $\sim 1-2 \%$ lower fluorescence quantum yield compared to the value determined in the absence of $\mathrm{CH}_{4}$. No literature value has been found for the quenching rate coefficient of $\mathrm{CH}_{3} \mathrm{O}(A)$ fluorescence by $\mathrm{H}_{2} \mathrm{O}$ vapour. However, even if it assumed to be as large as the above-reported value for $\mathrm{CH}_{4}\left(k_{\text {quench. }} \mathrm{CH}_{4}\right)$, only a few percent decrease in the fluorescence quantum yield is computed (compared with a water concentration of zero) for the levels of $\mathrm{H}_{2} \mathrm{O}$ vapour which are present at the $\mathrm{CH}_{3} \mathrm{O}_{2}$ FAGE detection axis when using the "wand" calibration method. These levels (1-2\% $v / v)$ are similar to a typical water vapour concentration in the atmosphere. A very good agreement has been obtained between the calibration factors for $\mathrm{CH}_{3} \mathrm{O}_{2}$ detection with two different concentrations of water vapour in the flow tube: $7.5 \times 10^{16}$ or $3.0 \times 10^{17}$ molecule $\mathrm{cm}^{-3}$ (corresponding to $2.6 \times 10^{14}$ and $1.0 \times 10^{15}$ molecule $\mathrm{cm}^{-3}$ respectively in the FAGE cell) as shown in Fig. 6 in Sect. 2.3.2. This very good agreement for $\mathrm{H}_{2} \mathrm{O}$ vapour and the above calculations for $\mathrm{CH}_{4}$ support the use of the flow-tube method for the FAGE calibration of the $\mathrm{CH}_{3} \mathrm{O}_{2}$ concentrations.

\subsubsection{Methyl peroxy calibration using kinetics of the $\mathrm{CH}_{3} \mathrm{O}_{2}$ second-order decay}

An alternative method of calibration for $\mathrm{CH}_{3} \mathrm{O}_{2}$ was to generate $\mathrm{CH}_{3} \mathrm{O}_{2}$ radicals in HIRAC to monitor the temporal decay of the $\mathrm{CH}_{3} \mathrm{O}_{2}$ FAGE signal once the photolysis lamps were turned off. Figure 7 shows an example of a decay in the $\mathrm{CH}_{3} \mathrm{O}_{2}$ signal generated by extinguishing the HIRAC lamps following the production of $\mathrm{CH}_{3} \mathrm{O}_{2}$ by the $\mathrm{Cl}$-atom-initiated oxidation of $\mathrm{CH}_{4}$ in the presence of $\mathrm{O}_{2}$ (Reactions $\mathrm{R} 12$ and $\mathrm{R} 2$ ). In the absence of other processes, the loss of $\mathrm{CH}_{3} \mathrm{O}_{2}$ is described by the integrated second-order rate law equation describing the $\mathrm{CH}_{3} \mathrm{O}_{2}$ self-reaction (Reaction R6):

$\frac{1}{\left[\mathrm{CH}_{3} \mathrm{O}_{2}\right]_{t}}=\frac{1}{\left[\mathrm{CH}_{3} \mathrm{O}_{2}\right]_{0}}+2 \cdot k_{\mathrm{obs}} t$

where $\left[\mathrm{CH}_{3} \mathrm{O}_{2}\right]_{t}$ is the methyl peroxy concentration at reaction time $t,\left[\mathrm{CH}_{3} \mathrm{O}_{2}\right]_{0}$ is the initial concentration when the lights are switched off and $k_{\text {obs }}$ is the observed rate coefficient (which is not equal to $k_{6}$, see below). Using $\left[\mathrm{CH}_{3} \mathrm{O}_{2}\right]=$ $\frac{S_{\mathrm{CH}_{3} \mathrm{O}_{2}}}{C_{\mathrm{CH}_{3} \mathrm{O}_{2}}}$, where $S_{\mathrm{CH}_{3} \mathrm{O}_{2}}$ is the signal measured by FAGE and $C_{\mathrm{CH}_{3} \mathrm{O}_{2}}$ is the instrument sensitivity, Eq. (6) is obtained for the temporal profile of the methyl peroxy signal:

$$
\begin{gathered}
\frac{1}{\left(S_{\mathrm{CH}_{3} \mathrm{O}_{2}}\right)_{t}}=\frac{1}{\left(S_{\left.\mathrm{CH}_{3} \mathrm{O}_{2}\right)_{0}}+\frac{2 \cdot k_{\mathrm{obs}} t}{C_{\mathrm{CH}_{3} \mathrm{O}_{2}}}\right. \text { or }} \\
\left(S_{\left.\mathrm{CH}_{3} \mathrm{O}_{2}\right)_{t}}=1 /\left(\frac{1}{\left(S_{\left.\mathrm{CH}_{3} \mathrm{O}_{2}\right)_{0}}\right.}+\frac{2 \cdot k_{\mathrm{obs}} t}{C_{\mathrm{CH}_{3} \mathrm{O}_{2}}}\right),\right.
\end{gathered}
$$

In Eq. (6) $\left(S_{\mathrm{CH}_{3} \mathrm{O}_{2}}\right)_{t}$ and $\left(S_{\mathrm{CH}_{3} \mathrm{O}_{2}}\right)_{0}$ are the signal at time $t$ and $t=0$ respectively.

Equation (6) was fitted to the experimental decays of $S_{\mathrm{CH}_{3} \mathrm{O}_{2}}$ (see Fig. 7 as an example) fixing $k_{\text {obs }}$ to the IUPAC recommendation, $k_{\mathrm{obs}}=(4.8 \pm 1.1) \times 10^{-13} \mathrm{~cm}^{3}$ molecule ${ }^{-1}$ $\mathrm{s}^{-1}$, in order to obtain $\mathrm{C}_{\mathrm{CH}_{3} \mathrm{O}_{2}}$. Eighteen $\mathrm{CH}_{3} \mathrm{O}_{2}$ decays were analysed, which yielded an average value of $C_{\mathrm{CH}_{3} \mathrm{O}_{2}}=$ $(5.6 \pm 1.7) \times 10^{-10}$ counts $\mathrm{cm}^{3}$ molecule $\mathrm{s}^{-1} \mathrm{~mW}^{-1}$. The error limit, $30 \%$, is the $2 \sigma$ composite error calculated as the sum in quadrature of the total systematic uncertainty, $29 \%$ (see Sect. 3.2.2), and the average random error of all determinations, with $8 \%$, taken as two standard errors in the fit of Eq. (6) to the $\mathrm{CH}_{3} \mathrm{O}_{2}$ temporal decays. This value agrees well with $C_{\mathrm{CH}_{3} \mathrm{O}_{2}}=(4.1 \pm 1.4) \times$ $10^{-10}$ counts $\mathrm{cm}^{3}$ molecule $\mathrm{e}^{-1} \mathrm{~s}^{-1} \mathrm{~mW}^{-1}$ obtained from the flow-tube calibration method (Sect. 3.1.1).

Based on the lack of a measurable $\mathrm{CH}_{3} \mathrm{O}_{2}$ radical gradient across HIRAC (Sect. 2.3.2., vide supra), it is assumed that the loss of $\mathrm{CH}_{3} \mathrm{O}_{2}$ to the walls of HIRAC in these experiments was negligible over the timescale of 1-2 min of the temporal decay measurements. Our finding is consistent with previous results showing that the heterogeneous wallloss rates for $\mathrm{CH}_{3} \mathrm{O}_{2}$ were significantly lower than the corresponding removal rates of $\mathrm{HO}_{2}$ (Miyazaki et al., 2010; Mihele et al., 1999; Fuchs et al., 2008). Using a $30 \mathrm{~cm}$ long 


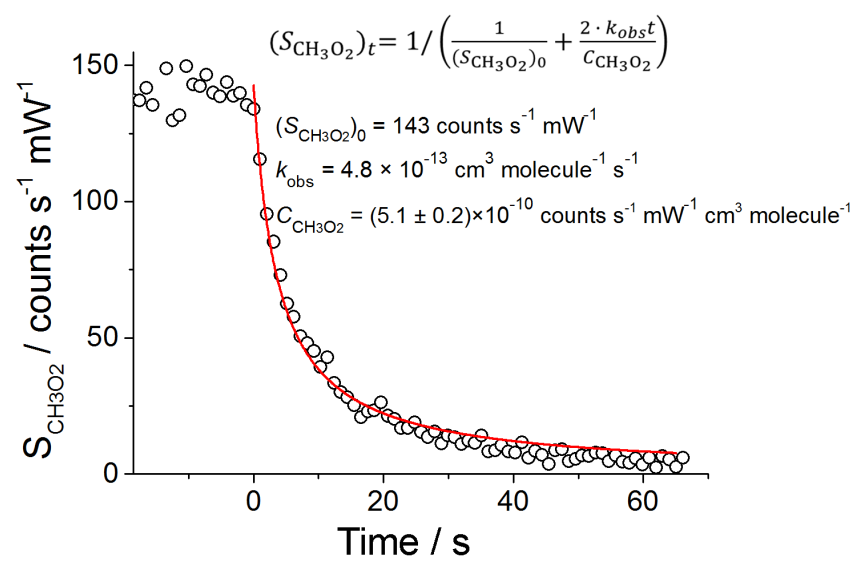

Figure 7. Second-order decay of the normalized $\mathrm{CH}_{3} \mathrm{O}_{2}$ signal with $1 \mathrm{~s}$ time resolution generated in HIRAC using $\mathrm{Cl} / \mathrm{CH}_{4} / \mathrm{O}_{2}$ and black lamps (see main text for details); $\left[\mathrm{CH}_{4}\right]_{0}=$ $2.3 \times 10^{17}$ molecule $\mathrm{cm}^{-3}$ and $\left[\mathrm{Cl}_{2}\right]_{0}=5.8 \times 10^{13}$ molecule $\mathrm{cm}^{-3}$ at $295 \mathrm{~K}$ and 1 bar mixture of $\mathrm{N}_{2}: \mathrm{O}_{2}=4: 1$. At time zero the lamps were turned off. Fitting Eq. (6) to the data yielded $C_{\mathrm{CH}_{3} \mathrm{O}_{2}}=$ $(5.1 \pm 0.2) \times 10^{-10}$ counts $\mathrm{cm}^{3}$ molecule ${ }^{-1} \mathrm{~s}^{-1} \mathrm{~mW}^{-1}$ (statistical error at $1 \sigma$ level).

glass tube of $2 \mathrm{~cm}$ diameter, Miyazaki et al. (2010) measured that the heterogeneous removal efficiency for $\mathrm{CH}_{3} \mathrm{O}_{2}$ was 6 times lower than for $\mathrm{HO}_{2}$. The $\mathrm{HO}_{2}$ wall-loss rate coefficient at room temperature and 1000 mbar in HIRAC was found to be of $\sim 10^{-2} \mathrm{~s}^{-1}$ (Winiberg et al., 2015). Therefore, it can be expected that the wall-loss rate coefficient of $\mathrm{CH}_{3} \mathrm{O}_{2}$ in HIRAC was $k_{\text {loss }} \cong 10^{-3} \mathrm{~s}^{-1}$ and so is not considered in the analysis here for $\mathrm{CH}_{3} \mathrm{O}_{2}$ decays which typically last for $\sim 100 \mathrm{~s}$. In order to investigate the sensitivity of $\mathrm{C}_{\mathrm{CH}_{3} \mathrm{O}_{2}}$ obtained by the kinetic analysis of the $\mathrm{CH}_{3} \mathrm{O}_{2}$ decay to $k_{\text {loss }}$ higher than $10^{-3} \mathrm{~s}^{-1}$, a wall-loss rate coefficient of $10^{-2} \mathrm{~s}^{-1}$ was included in the analysis of the experimental decays of $\mathrm{CH}_{3} \mathrm{O}_{2}$ to obtain $\mathrm{C}_{\mathrm{CH}_{3} \mathrm{O}_{2}}$, but only an increase in $\mathrm{C}_{\mathrm{CH}_{3} \mathrm{O}_{2}}$ of about $6 \%$ on average was seen. A small deviation of the experimental data from the fit was obtained at the end of the measurements whether or not $k_{\text {loss }}$ was included in the analysis (Fig. 7). The role of potential secondary chemistry at later times of the reaction will be investigated in future kinetic studies of the $\mathrm{CH}_{3} \mathrm{O}_{2}$ self-reaction.

Using the average sensitivity factor $C_{\mathrm{CH}_{3} \mathrm{O}_{2}}=(5.6 \pm$ 1.7) $\times 10^{-10}$ counts $\mathrm{cm}^{3}$ molecule ${ }^{-1} \mathrm{~s}^{-1} \mathrm{~mW}^{-1}$ determined by the $\mathrm{CH}_{3} \mathrm{O}_{2}$ decay method in HIRAC, and for a signal-tonoise ratio $S / N=2$, a laser power $P=15 \mathrm{~mW}$ and a time per data point $t=1 \mathrm{~s}$ in Eq. (4) results in an improved (compared with the flow-tube calibration) $\operatorname{LOD}\left(\mathrm{CH}_{3} \mathrm{O}_{2}\right)=2.8 \times$ $10^{8}$ molecule $\mathrm{cm}^{-3}$ for $5 \mathrm{~min}$ averaging time, i.e. 150 online data points $(m)$ and 150 offline points $(n)$. The corresponding LOD for an averaging time of $1 \mathrm{~h}$, i.e. $m=n=1800$, is $\operatorname{LOD}\left(\mathrm{CH}_{3} \mathrm{O}_{2}\right)=7.9 \times 10^{7}$ molecule $\mathrm{cm}^{-3}$.

It should be noted that the observed rate coefficient, $k_{\mathrm{obs}}$, is larger than the second-order rate coefficient of just the
$\mathrm{CH}_{3} \mathrm{O}_{2}$ recombination Reaction (R6), $k_{6}$, as the methoxy radicals generated by channel $\mathrm{R} 6 \mathrm{~b}$ react rapidly with molecular oxygen present in large excess, $5 \times 10^{18}$ molecule $\mathrm{cm}^{-3}$, to produce $\mathrm{HO}_{2}$ (Reaction R4) which in turn reacts with $\mathrm{CH}_{3} \mathrm{O}_{2}$ (Reaction R13):

$$
\begin{aligned}
& \mathrm{CH}_{3} \mathrm{O}_{2}+\mathrm{CH}_{3} \mathrm{O}_{2} \rightarrow \mathrm{CH}_{3} \mathrm{OH}+\mathrm{CH}_{2} \mathrm{O}+\mathrm{O}_{2}, \\
& \mathrm{CH}_{3} \mathrm{O}_{2}+\mathrm{CH}_{3} \mathrm{O}_{2} \rightarrow \mathrm{CH}_{3} \mathrm{O}+\mathrm{CH}_{3} \mathrm{O}+\mathrm{O}_{2}, \\
& \mathrm{CH}_{3} \mathrm{O}+\mathrm{O}_{2} \rightarrow \mathrm{CH}_{2} \mathrm{O}+\mathrm{HO}_{2}, \\
& \mathrm{CH}_{3} \mathrm{O}_{2}+\mathrm{HO}_{2} \rightarrow \mathrm{CH}_{3} \mathrm{OOH}+\mathrm{O}_{2}, \\
& \mathrm{CH}_{3} \mathrm{O}_{2}+\mathrm{HO}_{2} \rightarrow \mathrm{CH}_{2} \mathrm{O}+\mathrm{O}_{2}+\mathrm{H}_{2} \mathrm{O}
\end{aligned}
$$

As each $\mathrm{HO}_{2}$ radical consumes one $\mathrm{CH}_{3} \mathrm{O}_{2}$ species (Reacton R13) on the timescale of Reaction (R6), $k_{\mathrm{obs}}$ is given by (Sander and Watson, 1981; Lightfoot et al., 1990)

$k_{\mathrm{obs}}=k_{6}\left(1+r_{6 \mathrm{~b}}\right)$,

where $r_{6 \mathrm{~b}}$ is the branching ratio for the reaction channel R6b. According to IUPAC (Atkinson et al., 2006), there is a $23 \%$ uncertainty in $k_{\text {obs }}$ of the $\mathrm{CH}_{3} \mathrm{O}_{2}$ recombination at $298 \mathrm{~K}$ with a recommended value $k_{\mathrm{obs}}=4.8 \times 10^{-13} \mathrm{~cm}^{3}$ molecule ${ }^{-1} \mathrm{~s}^{-1}$. This value corresponds to $k_{6}=(3.5 \pm 1.0) \times 10^{-13} \mathrm{~cm}^{3}$ molecule ${ }^{-1} \mathrm{~s}^{-1}$ and $r_{6 \mathrm{~b}}=0.37 \pm 0.06$ (Atkinson et al., 2006).

In order to check the validity of Eq. (7) in the presence of $\mathrm{HO}_{2}$ removal by self-reaction and wall loss, numerical simulations were performed to generate $\mathrm{CH}_{3} \mathrm{O}_{2}$ decays using a system incorporating the chemistry described by Reactions (R4), (R6), (R13) and (R14) (vide infra) and a heterogeneous loss of $\mathrm{HO}_{2}, k_{\operatorname{loss}\left(\mathrm{HO}_{2}\right)}$ (see Supplement). The rate coefficients were sourced from the preferred IUPAC value at $298 \mathrm{~K}$ (Table S3 in Supplement) and $k_{\mathrm{loss}\left(\mathrm{HO}_{2}\right)}$ was varied. The simulated decays of $\left[\mathrm{CH}_{3} \mathrm{O}_{2}\right]$ vs. time were analysed using Eq. (5) (see Fig. S3 as an example) and gave an average observed rate coefficient of $k_{\text {obs }}=4.7 \times 10^{-13} \mathrm{~cm}^{3}$ molecule ${ }^{-1} \mathrm{~s}^{-1}$, which is only $2 \%$ lower than the IUPAC recommendation, for $k_{\operatorname{loss}\left(\mathrm{HO}_{2}\right)}$ varied between 0.01 and $0.10 \mathrm{~s}^{-1}$, and, hence confirm the applicability of Eq. (7).

$$
\begin{aligned}
& \mathrm{HO}_{2}+\mathrm{HO}_{2} \rightarrow \mathrm{H}_{2} \mathrm{O}_{2}+\mathrm{O}_{2} \\
& \mathrm{HO}_{2}+\mathrm{HO}_{2}+\mathrm{M} \rightarrow \mathrm{H}_{2} \mathrm{O}_{2}+\mathrm{O}_{2}+\mathrm{M}
\end{aligned}
$$

\subsection{Calibration uncertainties}

\subsubsection{Flow-tube method}

The $2 \sigma$ error associated with $C_{\mathrm{CH}_{3} \mathrm{O}_{2}}$ of $34 \%$ obtained by the flow-tube method $\left(C_{\mathrm{CH}_{3} \mathrm{O}_{2}}=(4.1 \pm 1.4) \times\right.$ $10^{-10}$ counts $\mathrm{cm}^{3}$ molecule $\left.\mathrm{e}^{-1} \mathrm{~s}^{-1} \mathrm{~mW}^{-1}\right)$ represents the overall uncertainty calculated using the sum in quadrature of the systematic uncertainty, $33 \%$, and the statistical error from the calibration plots, $\sim 8 \%$. The overall $34 \%$ uncertainty is similar to the previous estimated total uncertainty, 
$36 \%$, in the use of the same method for calibration of $\mathrm{OH}$ and $\mathrm{HO}_{2}$ measurements in HIRAC, where no $\mathrm{CH}_{4}$ is added (Winiberg et al., 2015). The flow-tube method is a proven method to generate known amounts of $\mathrm{OH}$ and $\mathrm{HO}_{2}$ by the photolysis of $\mathrm{H}_{2} \mathrm{O}$ at $184.9 \mathrm{~nm}$ in order to calibrate field instruments (Heard and Pilling, 2003).

The largest contribution to the total error of the method came from the $28 \%$ total uncertainty in the photon flux of the calibration source, $F_{184.9 n m}$. The product $F_{184.9 \mathrm{~nm}} \times \Delta t$ is determined using $\mathrm{N}_{2} \mathrm{O}$ actinometry relying on the measurement of $[\mathrm{NO}]$ in trace amounts $(0.2-1.5 \mathrm{ppbv})$ using a commercial NO analyser (Thermo Electron Corporation 42C) followed by the data analysis using four rate coefficients each with $\sim 10 \%$ uncertainty (Burkholder et al., 2015). Although it is the product $F_{184.9} \mathrm{~nm} \times \Delta t$ which is directly determined by the actinometric method and used to calculate the concentration of radicals to calibrate FAGE (Eq. 3), any difference in the volumetric flow rate between the calibration and actinometry experiments will change $\Delta t$. Therefore, the uncertainty in $\Delta t, 2 \%$, needs to be accounted for. The contributions from the rest of the terms in Eq. (3) to the systematic uncertainty in the determination of $\left[\mathrm{CH}_{3} \mathrm{O}_{2}\right]$ by this method were as follows: $6 \%$ total error in $\sigma_{\mathrm{H}_{2} \mathrm{O}}, 184.9 \mathrm{~nm}$ (Cantrell et al., 1997); $10 \%$ uncertainty in $\left[\mathrm{H}_{2} \mathrm{O}\right]$, taken from the instrumental uncertainty of the hygrometer; and $4 \%$ error in the yield of $\mathrm{CH}_{3} \mathrm{O}_{2}$ produced by the $\mathrm{OH}$ conversion into $\mathrm{CH}_{3}$ followed by the $\mathrm{CH}_{3}+\mathrm{O}_{2}$ reaction. The contribution of the uncertainties in the FAGE measurements to the $33 \%$ overall systematic uncertainty in the calibration were estimated to consist of $12 \%$ in the online FAGE signal and $6 \%$ uncertainty in the laser power measured by the laser power meter and used to normalise the data. The uncertainty associated with the online signal, $12 \%$ at $2 \sigma$ level, was calculated as the average deviation of the signal value due to the error limits of $\pm 5 \times 10^{-4} \mathrm{~nm}$ in the online wavelength position (see the typical laser excitation scans shown in Fig. 3).

\subsection{2 $\mathrm{CH}_{3} \mathrm{O}_{2}$ second-order decay calibration}

The largest contribution to the calculated overall $2 \sigma$ uncertainty of $30 \%$ in $\mathrm{C}_{\mathrm{CH}_{3} \mathrm{O}_{2}}$ obtained by the $\mathrm{CH}_{3} \mathrm{O}_{2}$ secondorder decay method $\left(C_{\mathrm{CH}_{3} \mathrm{O}_{2}}=(5.6 \pm 1.7) \times 10^{-10}\right.$ counts $\mathrm{cm}^{3}$ molecule $\left.{ }^{-1} \mathrm{~s}^{-1} \mathrm{~mW}^{-1}\right)$ derives from the $23 \%$ error in the IUPAC-preferred value of the observed rate coefficient for the effective $\mathrm{CH}_{3} \mathrm{O}_{2}$ self-reaction, $k_{\mathrm{obs}}=(4.8 \pm 1.1) \times$ $10^{-13} \mathrm{~cm}^{3}$ molecule $\mathrm{s}^{-1}$ (Atkinson et al., 2006). It is instructive to examine the origin of the $23 \%$ error. The studies which led to the IUPAC recommendation utilised the UV absorption of $\mathrm{CH}_{3} \mathrm{O}_{2}$, typically at $250 \mathrm{~nm}$, and the determined quantity was the ratio between the observed rate coefficient and the absorption cross section of $\mathrm{CH}_{3} \mathrm{O}_{2}, k_{\mathrm{obs}} / \sigma_{250} \mathrm{~nm}$. IUPAC and the Jet Propulsion Laboratory (JPL) recommend $3.9 \times 10^{-18}$ and $3.8 \times 10^{-18} \mathrm{~cm}^{2}$ molecule ${ }^{-1}$ respectively for $\sigma_{250 \mathrm{~nm}}$ (Atkinson et al., 2006; Burkholder et al., 2015). The JPL recommendation (Burkholder et al.,
2015 ) is the cross section obtained by the re-evaluation of the previous reported UV-absorption spectra by Tyndall et al. (2001) in 2001 (Tyndall et al., 2001), yielding $\sigma_{250 \mathrm{~nm}}=$ $3.78 \times 10^{-18} \mathrm{~cm}^{2}$ molecule ${ }^{-1}$. Tyndall et al. (2001) used a cross section of $(4.26 \pm 0.52) \times 10^{-18} \mathrm{~cm}^{2}$ molecule ${ }^{-1}$ (error at $2 \sigma$ ) for the maximum at $237.3 \mathrm{~nm}$, obtained by analysing the shape of the absorption spectra between 200 and $300 \mathrm{~nm}$ reported since 1990. The studies before 1990 were not included due to errors in the calibration of the $\mathrm{CH}_{3} \mathrm{O}_{2}$ cross section leading to large discrepancies in the reported values. The 2001 evaluation of Tyndall et al. (2001) calculated $k_{\mathrm{obs}}=$ $(4.7 \pm 0.8) \times 10^{-13} \mathrm{~cm}^{3}$ molecule $\mathrm{c}^{-1} \mathrm{~s}^{-1}$, where the error limits are two standard deviations of the mean. Including an error of $10 \%$ in the cross section of $\mathrm{CH}_{3} \mathrm{O}_{2}$, as suggested by the authors (Tyndall et al., 2001), a 19\% composite uncertainty in $k_{\text {obs }}$ is obtained. The result is in good agreement with the $23 \%$ uncertainty in the IUPAC recommendation.

The remaining contributions to the uncertainty in the calibration using the $\mathrm{CH}_{3} \mathrm{O}_{2}$ second-order decay method are a $6 \%$ error in the laser power, $12 \%$ uncertainty in the online signal determined by how well the laser is able to find the online wavelength position (vide supra) and $10 \%$ error in $\left(S_{\mathrm{CH}_{3} \mathrm{O}_{2}}\right)_{0}$ in Eq. (6), which is the value of the $\mathrm{CH}_{3} \mathrm{O}_{2}$ signal at the moment when the HIRAC lamps were turned off to generate a second-order decay.

\subsubsection{Comparison between the FAGE sensitivities for $\mathrm{CH}_{3} \mathrm{O}_{2}$ obtained by the two calibration methods}

The FAGE sensitivity factor obtained using the flow-tube method, $\quad C_{\mathrm{CH}_{3} \mathrm{O}_{2}}=(4.1 \pm 1.4) \times$ $10^{-10}$ counts $\mathrm{cm}^{3}$ molecule $\mathrm{s}^{-1} \mathrm{~mW}^{-1}$, is $27 \%$ lower but has overlapping error limits with the result found using the $\mathrm{CH}_{3} \mathrm{O}_{2}$ second-order decay method, $\mathrm{C}_{\mathrm{CH}_{3} \mathrm{O}_{2}}=$ $(5.6 \pm 1.7) \times 10^{-10}$ counts $\mathrm{cm}^{3}$ molecule ${ }^{-1} \mathrm{~s}^{-1} \mathrm{~mW}^{-1}$ (uncertainties quoted to $2 \sigma$ ). The calculated overall error in the $\mathrm{CH}_{3} \mathrm{O}_{2}$ second-order decay method, $30 \%$, is similar to the total uncertainty in the flow-tube method, $34 \%$. The flow-tube method is known to reliably generate accurate concentrations of radicals and has been used for many years in the calibration of FAGE instruments employed in field measurements of $\mathrm{OH}$ and $\mathrm{HO}_{2}$ (Heard and Pilling, 2003). The flow-tube method has also been validated by using alternate methods of calibration, for example using the decay of a hydrocarbon in the HIRAC chamber to obtain $[\mathrm{OH}]$ (Winiberg et al., 2015). The method of using a time-resolved kinetic quantity to derive a calibration factor was validated for $\mathrm{HO}_{2}$ in HIRAC, where $C_{\mathrm{HO}_{2}}$ obtained from analysis of the temporal decay of $\mathrm{HO}_{2}$ agreed with $C_{\mathrm{HO}_{2}}$ from the flow-tube method (Winiberg et al., 2015). These results suggests that the sensitivity of the FAGE system, represented by the value of $C$, is not changed between sampling from the calibration flow tube and sampling from within HIRAC itself. 
The accuracy of the $\mathrm{CH}_{3} \mathrm{O}_{2}$ temporal decay method is largely determined by the accuracy of $k_{\mathrm{obs}}$ (see Sect.3.2.2. above). The quantity measured in the previous kinetic studies of $\mathrm{CH}_{3} \mathrm{O}_{2}+\mathrm{CH}_{3} \mathrm{O}_{2}$ is $k_{\text {obs }} / \sigma_{250} \mathrm{~nm}$ and hence the accuracy of $k_{\text {obs }}$ is directly affected by any systematic errors in the determination of $\sigma_{250 \mathrm{~nm}}$. In order to make $C_{\mathrm{CH}_{3} \mathrm{O}_{2}}$ derived from the temporal decay and flow-tube methods of the same, the value of $k_{\text {obs }}$ would need to be reduced by $\sim 25 \%$, which in turn requires a $\sim 25 \%$ reduction in $\sigma_{250} \mathrm{~nm}$. It is noted that the UV-absorption spectrum of $\mathrm{CH}_{3} \mathrm{O}_{2}$ is relatively broad and hence may prevent a selective detection due to the difficulty in discriminating from the potential presence of other species also absorbing around $250 \mathrm{~nm}$, such as $\mathrm{Cl}_{2}$ and $\mathrm{CH}_{3} \mathrm{CHO}$ used in concentrations as high as $10^{16}$ molecule $\mathrm{cm}^{-3}$, while $\left[\mathrm{CH}_{3} \mathrm{O}_{2}\right]$ was $\sim 10^{13}$ molecule $\mathrm{cm}^{-3}$ (Dagaut and Kurylo, 1990; Roehl et al., 1996). As the absorption cross sections of $\mathrm{Cl}_{2}$ and $\mathrm{CH}_{3} \mathrm{CHO}$ at $250 \mathrm{~nm}$ lay in the range $10^{-21}$ $10^{-22} \mathrm{~cm}^{2}$ molecule ${ }^{-1}$ (Keller-Rudek et al., 2013), the unaccounted for absorption of these species may have led to an overestimation of $\sigma_{250 \mathrm{~nm}}\left(\mathrm{CH}_{3} \mathrm{O}_{2}\right)$.

As noted in the 2001 review by Tyndall et al. (2001), none of the previous laboratory studies of the $\mathrm{CH}_{3} \mathrm{O}_{2}$ recombination measured $\left[\mathrm{CH}_{3} \mathrm{O}_{2}\right]$ by any method other than UV-spectroscopy. In addition, the traditional time-resolved measurements of $\mathrm{CH}_{3} \mathrm{O}_{2}$ used high $\mathrm{CH}_{3} \mathrm{O}_{2}$ concentrations $\left(10^{13}-10^{15}\right.$ molecule $\left.\mathrm{cm}^{-3}\right)$ and, as the self-reaction is fairly slow, Tyndall et al. (2001) stated that the results were potentially affected by secondary chemistry (Tyndall et al., 2001). Therefore, there is a need for the use of a complementary technique in the kinetic study of this reaction, for example by LIF as described in this paper, which may offer some advantages to probe $\mathrm{CH}_{3} \mathrm{O}_{2}$ selectively in the absence of interferences from other species. In addition, LIF is more sensitive and hence requires significantly lower radical concentrations $\left(\left[\mathrm{CH}_{3} \mathrm{O}_{2}\right]_{0}=(1-3) \times 10^{11}\right.$ molecule $\mathrm{cm}^{-3}$ here $)$ than the UV-absorption studies, which may help to minimise potential secondary chemistry.

\subsection{Methoxy radical measurement within HIRAC}

The typical concentration of $\left[\mathrm{O}_{2}\right]=5 \times 10^{18}$ molecule $\mathrm{cm}^{-3}$ used in the HIRAC experiments described above was lowered in some experiments to decrease the consumption of $\mathrm{CH}_{3} \mathrm{O}$ by $\mathrm{O}_{2}$ via Reaction (R4). In this manner, a concentration of methoxy radicals was obtained above the FAGE limit of detection in HIRAC to enable a direct measurement over a few minutes. The chamber was filled with high purity nitrogen $(>99.998 \%$ ), but the $\sim 6 \mathrm{~m}$ long $\mathrm{N}_{2}$ delivery pipe was purposely incompletely purged before the experiment in order to deliver trace levels of oxygen to HIRAC. The initial $\mathrm{Cl}_{2}$ concentration in these experiments was $5.6 \times 10^{15}$ molecule $\mathrm{cm}^{-3}$ and hence was $1-2$ orders of magnitude higher than $\left[\mathrm{Cl}_{2}\right]_{0}$ used in the kinetic experiments above in order to generate higher $[\mathrm{Cl}]$ and hence $\left[\mathrm{CH}_{3} \mathrm{O}\right]$. The concentration of $\mathrm{CH}_{3} \mathrm{O}$ during the experiment was computed by using the FAGE calibration factor for methoxy radicals generated from the photolysis of methanol in $\mathrm{N}_{2}, C_{\mathrm{CH}_{3} \mathrm{O}}=$ $(5.1 \pm 2.2) \times 10^{-10}$ counts $\mathrm{cm}^{3}$ molecule ${ }^{-1} \mathrm{~s}^{-1} \mathrm{~mW}^{-1}$

(Sect. 3.1.1). The temporal profile of $\mathrm{CH}_{3} \mathrm{O}$ is shown in Fig. 8, together with a numerical simulation of $\mathrm{CH}_{3} \mathrm{O}(t)$, using a chemistry system described in the Supplement. The best fit to the experimental $\mathrm{CH}_{3} \mathrm{O}$ concentration profile was obtained for $\left[\mathrm{O}_{2}\right]=(5.4 \pm 0.6) \times 10^{15}$ molecule $\mathrm{cm}^{-3}$, i.e. around $0.02 \%$ relative to $\mathrm{N}_{2}$. The numerical simulations showed that $\mathrm{Cl}_{2}$ consumption was dominated by the reaction with $\mathrm{CH}_{3}$ radicals, present at a relatively high concentration, explaining the $\sim 50 \%$ decrease in $\left[\mathrm{CH}_{3} \mathrm{O}\right]$ observed during its temporal measurement shown in Fig. 8. The Supplement (Fig. S5) shows the concentration profiles of $\mathrm{Cl}_{2}, \mathrm{Cl}, \mathrm{CH}_{3}$ and $\mathrm{CH}_{3} \mathrm{O}_{2}$ obtained by numerical simulations performed over $\sim 2$ min.

These results demonstrate the capability to measure an absolute concentration of $\mathrm{CH}_{3} \mathrm{O}$ radicals in a simulation chamber, with $\mathrm{CH}_{3} \mathrm{O}$ representing a further model target species for the validation of chemical mechanisms for the chemical oxidation of VOCs. However, it is recognised that the experiments need to be performed at reduced $\left[\mathrm{O}_{2}\right]$ and that $\left[\mathrm{O}_{2}\right]$ needs to be known a priori in order to test robustly the accuracy of the chemical mechanism and underlying kinetic parameters.

\section{Conclusions}

Currently there is no measurement of the absolute concentration of $\mathrm{CH}_{3} \mathrm{O}_{2}$ radicals in the atmosphere. In this work the FAGE technique has been extended by adding the capability to detect $\mathrm{CH}_{3} \mathrm{O}_{2}$ and $\mathrm{CH}_{3} \mathrm{O}$ radicals to the more typical measurement of $\mathrm{OH}$ and $\mathrm{HO}_{2}$ radicals. The method enables the speciated and sensitive detection of $\mathrm{CH}_{3} \mathrm{O}_{2}$ radicals by converting $\mathrm{CH}_{3} \mathrm{O}_{2}$ into $\mathrm{CH}_{3} \mathrm{O}$ by reaction with $\mathrm{NO}$ and detecting the resultant $\mathrm{CH}_{3} \mathrm{O}$ by LIF with excitation at ca. $298 \mathrm{~nm}$. The limit of detection of the method obtained using the radical source commonly employed to provide accurate concentrations of $\mathrm{OH}$ with added $\mathrm{CH}_{4}$ is $3.8 \times 10^{8}$ molecule $\mathrm{cm}^{-3}$ for a signal-to-noise ratio of 2 and $5 \mathrm{~min}$ time resolution and reduces to $1.1 \times 10^{8}$ molecule $\mathrm{cm}^{-3}$ for $S / N=2$ and $1 \mathrm{~h}$ averaging time. Therefore, the method has the potential to be used in field measurements of the diurnal profiles of $\mathrm{CH}_{3} \mathrm{O}_{2}$ in clean air with low $\mathrm{NO}_{x}$ levels, such as remote continental environments and in the marine boundary layer. Further improvements of the FAGE sensitivity could be achieved via the increase in the laser repetition frequency above the current value of $5 \mathrm{kHz}$, a decrease in the detection chamber pressure (currently $\sim 2.65$ Torr), and the use of a shorter distance between the inlet sampling pinhole and the fluorescence detection axis (presently a long distance of $\sim 580 \mathrm{~mm}$ ). The method is also demonstrated for the direct detection of $\mathrm{CH}_{3} \mathrm{O}$, in the absence of added $\mathrm{NO}$ to the fluorescence cell. 


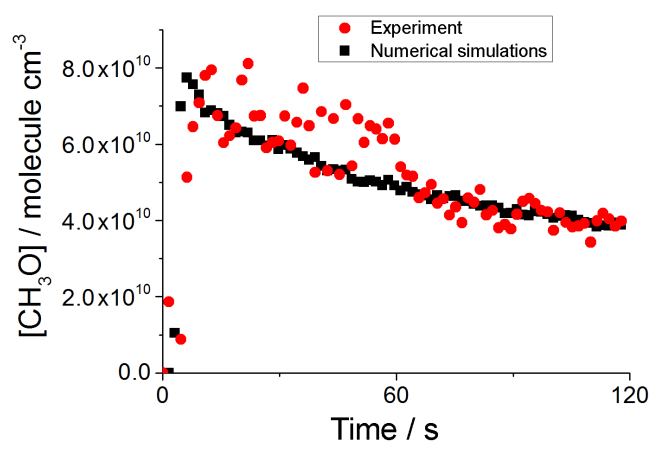

Figure 8. Concentration of $\mathrm{CH}_{3} \mathrm{O}$ as a function of time in HIRAC: red points are the experimental data and black points are generated by a numerical simulation. $\mathrm{CH}_{3} \mathrm{O}$ radicals were formed as a product of the self-reaction of $\mathrm{CH}_{3} \mathrm{O}_{2}$ species at $295 \mathrm{~K}$ and 1 bar of $\mathrm{N}_{2}$, with $\mathrm{CH}_{3} \mathrm{O}_{2}$ generated by the reaction of $\mathrm{Cl}$ atoms with $\mathrm{CH}_{4}$, and with the HIRAC black lamps being turned on at time zero. Oxygen was present in trace amounts, determined to be $(5.4 \pm 0.6) \times 10^{15}$ molecule $\mathrm{cm}^{-3}$ from comparison of the simulations to the experimental data. The chemical mechanism used in the numerical simulations is presented in the Supplement.

The limit of detection for $\mathrm{CH}_{3} \mathrm{O}$ determined using the conventional radical source for $S / N=2$ and 5 min averaging time is $3.0 \times 10^{8}$ molecule $\mathrm{cm}^{-3}$.

Additional investigations into the FAGE sensitivity for $\mathrm{CH}_{3} \mathrm{O}_{2}$ were carried out in the HIRAC simulation chamber at Leeds, by studying the kinetics of the second-order decays of $\mathrm{CH}_{3} \mathrm{O}_{2}$ by its self-reaction. The second-order decays of $\mathrm{CH}_{3} \mathrm{O}_{2}$ were analysed by fixing the observed rate coefficient to the IUPAC recommendation, $k_{\text {obs }}=(4.8 \pm 1.1) \times 10^{-13} \mathrm{~cm}^{3}$ molecule $\mathrm{e}^{-1} \mathrm{~s}^{-1}$ (Atkinson et al., 2006), in the fitting routine to extract the FAGE sensitivity factor for $\mathrm{CH}_{3} \mathrm{O}_{2}, C_{\mathrm{CH}_{3} \mathrm{O}_{2}}$. The obtained value, $C_{\mathrm{CH}_{3} \mathrm{O}_{2}}=$ $(5.6 \pm 0.9) \times 10^{-10}$ counts $\mathrm{cm}^{3}$ molecule ${ }^{-1} \mathrm{~s}^{-1} \mathrm{~mW}^{-1}$, agrees well with the result found using the conventional radical source, $C_{\mathrm{CH}_{3} \mathrm{O}_{2}}=(4.1 \pm 0.7) \times$ $10^{-10}$ counts $\mathrm{cm}^{3}$ molecule ${ }^{-1} \mathrm{~s}^{-1} \mathrm{~mW}^{-1}$ (uncertainties quoted to $1 \sigma$ ). The two values have overlapping error limits at $1 \sigma$ level.

In addition to the quantitative detection of $\mathrm{CH}_{3} \mathrm{O}_{2}$, experiments were carried out to measure $\mathrm{CH}_{3} \mathrm{O}$ generated as a product by the $\mathrm{CH}_{3} \mathrm{O}_{2}$ self-reaction in HIRAC. Oxygen was present at a significantly lower concentration to reduce the consumption rate of $\mathrm{CH}_{3} \mathrm{O}$ by reaction with $\mathrm{O}_{2}$ in order to enable the measurement. Good agreement between the experimental data and $\left[\mathrm{CH}_{3} \mathrm{O}\right]$ generated by numerical simulations using a model describing the chemical system was obtained, demonstrating the capability to quantitatively measure $\mathrm{CH}_{3} \mathrm{O}$. In addition to $\mathrm{CH}_{3} \mathrm{O}_{2}$, a measurement of $\mathrm{CH}_{3} \mathrm{O}$ will be useful as a further model target in future mechanistic studies of atmospherically relevant chemical systems within HIRAC.
Data availability. Data presented in this study are available from the authors upon request.

\section{The Supplement related to this article is available online at https://doi.org/10.5194/amt-10-3985-2017-supplement.}

Competing interests. The authors declare that they have no conflict of interest.

Acknowledgements. This work was supported by the Natural Environment Research Council (grant number NE/M011208/1) and the National Centre for Atmospheric Science, and AB is grateful to NERC for a studentship, awarded as part of the SPHERES doctoral training programme (NE/L002574/1). The authors thank Bethany Ronnie for help with the measurements of methyl peroxy concentrations across HIRAC.

Edited by: Andreas Hofzumahaus

Reviewed by: three anonymous referees

\section{References}

Albaladejo, J., Jimenez, E., Notario, A., Cabanas, B., and Martinez, E.: $\mathrm{CH}_{3} \mathrm{O}$ yield in the $\mathrm{CH}_{3}+\mathrm{O}_{3}$ reaction using the LP/LIF technique at room temperature, J. Phys. Chem. A, 106, 2512-2519, https://doi.org/10.1021/jp012249o, 2002.

Atkinson, R., Baulch, D. L., Cox, R. A., Crowley, J. N., Hampson, R. F., Hynes, R. G., Jenkin, M. E., Rossi, M. J., Troe, J., and IUPAC Subcommittee: Evaluated kinetic and photochemical data for atmospheric chemistry: Volume II - gas phase reactions of organic species, Atmos. Chem. Phys., 6, 3625-4055, https://doi.org/10.5194/acp-6-3625-2006, 2006.

Biggs, P., Canosa-Mas, C. E., Fracheboud, J. M., Parr, A. D., Shallcross, D. E., Wayne, R. P., and Caralp, F.: Investigation into the pressure dependence between 1 and 10 Torr of the reactions of $\mathrm{NO}_{2}$ with $\mathrm{CH}_{3}$ and $\mathrm{CH}_{3} \mathrm{O}$, J. Chem. Soc. Faraday T., 89, 4163 4169, https://doi.org/10.1039/ft9938904163, 1993.

Biggs, P., Canosa-Mas, C. E., Fracheboud, J. M., Shallcross, D. E., and Wayne, R. P.: Kinetics of the reaction of $\mathrm{F}$ atoms with $\mathrm{CH}_{3} \mathrm{ONO}$ and $\mathrm{CH}_{3} \mathrm{O}$, and the reaction of $\mathrm{CH}_{3} \mathrm{O}$ with a number of hydrocarbons, J. Chem. Soc. Faraday T., 93, 2481-2486, https://doi.org/10.1039/a701175j, 1997.

Bossolasco, A., Farago, E. P., Schoemaecker, C., and Fittschen, C.: Rate constant of the reaction between $\mathrm{CH}_{3} \mathrm{O}_{2}$ and $\mathrm{OH}$ radicals, Chem. Phys. Lett., 593, 7-13, https://doi.org/10.1016/j.cplett.2013.12.052, 2014.

Buenker, R. J., Olbrich, G., Schuchmann, H. P., Schurmann, B. L., and Vonsonntag, C.: Photolysis of methanol at $185 \mathrm{~nm}$. Quantum mechanical calculations and product study, J. Am. Chem. Soc., 106, 4362-4368, https://doi.org/10.1021/ja00328a011, 1984.

Burkholder, J. B., Sander, S. P., Abbatt, J. P. D., Barker, J. R., Huie, R. E., Kolb, C. E., Kurylo, M. J., Orkin, V. L., Wilmouth, D. M., and Wine, P. H.: Chemical kinetics and photochemical data for 
use in atmospheric studies - Evaluation No. 18, JPL Publication 15-10, available at: http://jpldataeval.jpl.nasa.gov/ (last access: 22 February 2017), 2015.

Cantrell, C. A. and Stedman, D. H.: A possible technique for the measurement of atmospheric peroxy-radicals, Geophys. Res. Lett., 9, 846-849, https://doi.org/10.1029/GL009i008p00846, 1982.

Cantrell, C. A., Stedman, D. H., and Wendel, G. J.: Measurement of atmospheric peroxy-radicals by chemical amplification, Anal. Chem., 56, 1496-1502, https://doi.org/10.1021/ac00272a065, 1984.

Cantrell, C. A., Zimmer, A., and Tyndall, G. S.: Absorption cross sections for water vapor from 183 to $193 \mathrm{~nm}$, Geophys. Res. Lett., 24, 2195-2198, https://doi.org/10.1029/97g102100, 1997.

Chai, J. J., Hu, H. Y., Dibble, T. S., Tyndall, G. S., and Orlando, J. J.: Rate Constants and Kinetic Isotope Effects for Methoxy Radical Reacting with $\mathrm{NO}_{2}$ and $\mathrm{O}_{2}$, J. Phys. Chem. A, 118, 3552-3563, https://doi.org/10.1021/jp501205d, 2014.

Chen, Y., Yang, C., Zhao, W., Fang, B., Xu, X., Gai, Y., Lin, X., Chen, W., and Zhang, W.: Ultra-sensitive measurement of peroxy radicals by chemical amplification broadband cavity-enhanced spectroscopy, Analyst, 141, 5870-5878, https://doi.org/10.1039/c6an01038e, 2016.

Creasey, D. J., Heard, D. E., and Lee, J. D.: Absorption crosssection measurements of water vapour and oxygen at $185 \mathrm{~nm}$. Implications for the calibration of field instruments to measure $\mathrm{OH}, \mathrm{HO}_{2}$ and $\mathrm{RO}_{2}$ radicals, Geophys. Res. Lett., 27, 1651-1654, https://doi.org/10.1029/1999gl011014, 2000.

Dagaut, P. and Kurylo, M. J.: The gas phase UV absorption spectrum of $\mathrm{CH}_{3} \mathrm{O}_{2}$ radicals: A reinvestigation, J. Photoch. Photobio. A, 51, 133-140, https://doi.org/10.1016/1010-6030(90)87047-f, 1990.

Dillon, T. J., Holscher, D., Sivakumaran, V., Horowitz, A., and Crowley, J. N.: Kinetics of the reactions of HO with methanol (210-351 K) and with ethanol (216-368 K), Phys. Chem. Chem. Phys., 7, 349-355, https://doi.org/10.1039/b413961e, 2005.

Ebata, T., Yanagishita, H., Obi, K., and Tanaka, I.: A-X Fluorescence-Spectra of $\mathrm{CH}_{3} \mathrm{O}$ and $\mathrm{C}_{2} \mathrm{H}_{5} \mathrm{O}$ Generated by the ArF Laser Photolysis of Alkyl Nitrites, Chem. Phys., 69, 27-33, https://doi.org/10.1016/0301-0104(82)88129-9, 1982.

Edwards, G. D., Cantrell, C. A., Stephens, S., Hill, B., Goyea, O., Shetter, R. E., Mauldin, R. L., Kosciuch, E., Tanner, D. J., and Eisele, F. L.: Chemical ionization mass spectrometer instrument for the measurement of tropospheric $\mathrm{HO}_{2}$ and $\mathrm{RO}_{2}$, Anal. Chem., 75, 5317-5327, https://doi.org/10.1021/ac034402b, 2003.

Farago, E. P., Viskolcz, B., Schoemaecker, C., and Fittschen, C.: Absorption Spectrum and Absolute Absorption Cross Sections of $\mathrm{CH}_{3} \mathrm{O}_{2}$ Radicals and $\mathrm{CH}_{3} \mathrm{I}$ Molecules in the Wavelength Range 7473-7497 cm ${ }^{-1}$, J. Phys. Chem. A, 117, 12802-12811, https://doi.org/10.1021/jp408686s, 2013.

Fuchs, H., Holland, F., and Hofzumahaus, A.: Measurement of tropospheric $\mathrm{RO}_{2}$ and $\mathrm{HO}_{2}$ radicals by a laser-induced fluorescence instrument, Rev. Sci. Instrum., 79, 084104, https://doi.org/10.1063/1.2968712, 2008.

Glowacki, D. R., Goddard, A., Hemavibool, K., Malkin, T. L., Commane, R., Anderson, F., Bloss, W. J., Heard, D. E., Ingham, T., Pilling, M. J., and Seakins, P. W.: Design of and initial results from a Highly Instrumented Reactor for Atmo- spheric Chemistry (HIRAC), Atmos. Chem. Phys., 7, 53715390, https://doi.org/10.5194/acp-7-5371-2007, 2007.

Green, T. J., Reeves, C. E., Fleming, Z. L., Brough, N., Rickard, A. R., Bandy, B. J., Monks, P. S., and Penkett, S. A.: An improved dual channel PERCA instrument for atmospheric measurements of peroxy radicals, J. Environ. Monitor., 8, 530-536, https://doi.org/10.1039/b514630e, 2006.

Hanke, M., Uecker, J., Reiner, T., and Arnold, F.: Atmospheric peroxy radicals: ROXMAS, a new mass-spectrometric methodology for speciated measurements of $\mathrm{HO}_{2}$ and $\Sigma \mathrm{RO}_{2}$ and first results, Int. J. Mass Spectrom., 213, 91-99, https://doi.org/10.1016/s1387-3806(01)00548-6, 2002.

Heard, D. E. and Pilling, M. J.: Measurement of $\mathrm{OH}$ and $\mathrm{HO}_{2}$ in the troposphere, Chem. Rev., 103, 5163-5198, https://doi.org/10.1021/cr020522s, 2003.

Hernandez, M. D. A., Burkert, J., Reichert, L., Stobener, D., Meyer-Arnek, J., Burrows, J. P., Dickerson, R. R., and Doddridge, B. G.: Marine boundary layer peroxy radical chemistry during the AEROSOLS99 campaign: Measurements and analysis, J. Geophys. Res.-Atmos., 106, 20833-20846, https://doi.org/10.1029/2001jd900113, 2001.

Inoue, G., Akimoto, H., and Okuda, M.: Laser-induced fluorescence spectra of $\mathrm{CH}_{3} \mathrm{O}$, Chem. Phys. Lett., 63, 213-216, https://doi.org/10.1016/0009-2614(79)87002-5, 1979.

Inoue, G., Akimoto, $\mathrm{H}$., and Okuda, $\mathrm{M}$.: Spectroscopy of the $\mathrm{CH}_{3} \mathrm{O}$ $\mathrm{A}^{2} \mathrm{~A}_{1}-\mathrm{X}{ }^{2} \mathrm{E}$ system by laser-excited fluorescence method, J. Chem. Phys., 72, 1769-1775, https://doi.org/10.1063/1.439291, 1980.

Jenkin, M. E., Cox, R. A., Hayman, G. D., and Whyte, L. J.: Kinetic study of the reactions $\mathrm{CH}_{3} \mathrm{O}_{2}+\mathrm{CH}_{3} \mathrm{O}_{2}$ and $\mathrm{CH}_{3} \mathrm{O}_{2}+\mathrm{HO}_{2}$ using molecular modulation spectroscopy, J. Chem. Soc. Farad. T. 2, 84, 913-930, https://doi.org/10.1039/f29888400913, 1988.

Jenkin, M. E., Young, J. C., and Rickard, A. R.: The MCM v3.3.1 degradation scheme for isoprene, Atmos. Chem. Phys., 15, 11433-11459, https://doi.org/10.5194/acp-15-11433-2015, 2015.

Jimenez, E., Gilles, M. K., and Ravishankara, A. R.: Kinetics of the reactions of the hydroxyl radical with $\mathrm{CH}_{3} \mathrm{OH}$ and $\mathrm{C}_{2} \mathrm{H}_{5} \mathrm{OH}$ between 235 and 360 K, J. Photoch. Photobio. A, 157, 237-245, https://doi.org/10.1016/s1010-6030(03)00073-x, 2003.

Kappert, J. and Temps, F.: Rotationally resolved laser-induced fluorescence excitation studies of $\mathrm{CH}_{3} \mathrm{O}$, Chem. Phys., 132, 197208, https://doi.org/10.1016/0301-0104(89)80088-6, 1989.

Kassab, E., Gleghorn, J. T., and Evleth, E. M.: Theoretical aspects of the photochemistry of methanol, methylamine, and related materials, J. Am. Chem. Soc., 105, 1746-1753, https://doi.org/10.1021/ja00345a008, 1983.

Keller-Rudek, H., Moortgat, G. K., Sander, R., and Sörensen, R.: The MPI-Mainz UV/VIS Spectral Atlas of Gaseous Molecules of Atmospheric Interest, Earth Syst. Sci. Data, 5, 365-373, https://doi.org/10.5194/essd-5-365-2013, 2013.

Kurylo, M. J. and Wallington, T. J.: The temperature dependence of the rate constant for the gas phase disproportionation reaction of $\mathrm{CH}_{3} \mathrm{O}_{2}$ radicals, Chem. Phys. Lett., 138, 543-547, https://doi.org/10.1016/0009-2614(87)80121-5, 1987.

Lightfoot, P. D., Lesclaux, R., and Veyret, B.: Flash photolysis study of the $\mathrm{CH}_{3} \mathrm{O}_{2}+\mathrm{CH}_{3} \mathrm{O}_{2}$ reaction: Rate constants and branching ratios from 248 to $573 \mathrm{~K}$, J. Phys. Chem., 94, 700-707, https://doi.org/10.1021/j100365a035, 1990. 
Malkin, T. L., Goddard, A., Heard, D. E., and Seakins, P. W.: Measurements of $\mathrm{OH}$ and $\mathrm{HO}_{2}$ yields from the gas phase ozonolysis of isoprene, Atmos. Chem. Phys., 10, 1441-1459, https://doi.org/10.5194/acp-10-1441-2010, 2010.

Marston, C. C., Weide, K., Schinke, R., and Suter, H. U.: Product selectivity of vibrationally mediated photofragmentation of methanol, J. Chem. Phys., 98, 4718-4727, https://doi.org/10.1063/1.464976, 1993.

McAdam, K., Veyret, B., and Lesclaux, R.: UV absorption spectra of $\mathrm{HO}_{2}$ and $\mathrm{CH}_{3} \mathrm{O}_{2}$ radicals and the kinetics of their mutual reactions ant $298 \mathrm{~K}$, Chem. Phys. Lett., 133, 39-44, https://doi.org/10.1016/0009-2614(87)80049-0, 1987.

Mihele, C. M., Mozurkewich, M., and Hastie, D. R.: Radical loss in a chain reaction of $\mathrm{CO}$ and $\mathrm{NO}$ in the presence of water: Implications for the radical amplifier and atmospheric chemistry, Int. J. Chem. Kinet., 31, 145-152, https://doi.org/10.1002/(sici)10974601(1999)31:2<145::aid-kin7>3.0.co;2-m, 1999.

Miyazaki, K., Parker, A. E., Fittschen, C., Monks, P. S., and Kajii, Y.: A new technique for the selective measurement of atmospheric peroxy radical concentrations of $\mathrm{HO}_{2}$ and $\mathrm{RO}_{2}$ using a denuding method, Atmos. Meas. Tech., 3, 1547-1554, https://doi.org/10.5194/amt-3-1547-2010, 2010.

Nagesh, J., Sibert, E. L., and Stanton, J. F.: Simulation of $\mathrm{A}^{2} \mathrm{~A}_{1}<-\mathrm{X}^{2} \mathrm{E}$ laser excitation spectrum of $\mathrm{CH}_{3} \mathrm{O}$ and $\mathrm{CD}_{3} \mathrm{O}$, Spectrochim. Acta A, 119, 90-99, https://doi.org/10.1016/j.saa.2013.02.037, 2014.

Nee, J. B., Suto, M., and Lee, L. C.: Photoexcitation processes of $\mathrm{CH}_{3} \mathrm{OH}$ : Rydberg states and photofragment fluorescence, Chem. Phys., 98, 147-155, https://doi.org/10.1016/03010104(85)80102-6, 1985

Orlando, J. J. and Tyndall, G. S.: Laboratory studies of organic peroxy radical chemistry: an overview with emphasis on recent issues of atmospheric significance, Chem. Soc. Rev., 41, 82138213, 2012.

Porter, R. P. and Noyes, W. A.: Photochemical studies, LIV. Methanol vapor, J. Am. Chem. Soc., 81, 2307-2311, https://doi.org/10.1021/ja01519a007, 1959.

Powers, D. E., Pushkarsky, M. B., and Miller, T. A.: Rovibronic analysis of the laser induced fluorescence excitation spectrum of the jet-cooled methoxy radical, J. Chem. Phys., 106, 6863-6877, https://doi.org/10.1063/1.473712, 1997.

Roehl, C. M., Bauer, D., and Moortgat, G. K.: Absorption spectrum and kinetics of the acetylperoxy radical, J. Phys. Chem., 100, 4038-4047, https://doi.org/10.1021/jp9526298, 1996.

Sander, S. P. and Watson, R. T.: Kinetic studies of the reactions of $\mathrm{CH}_{3} \mathrm{O}_{2}$ with $\mathrm{NO}, \mathrm{NO}_{2}$ and $\mathrm{CH}_{3} \mathrm{O}_{2}$ at $298 \mathrm{~K}$, J. Phys. Chem., 84, 1664-1674, https://doi.org/10.1021/j100450a002, 1980.

Sander, S. P. and Watson, R. T.: Temperature dependence of the self-reaction of $\mathrm{CH}_{3} \mathrm{O}_{2}$ radicals, J. Phys. Chem., 85, 2960-2964, https://doi.org/10.1021/j150620a023, 1981.

Satyapal, S., Park, J., Bersohn, R., and Katz, B.: Dissociation of methanol and ethanol activated by a chemicalreaction or by light, J. Chem. Phys., 91, 6873-6879, https://doi.org/10.1063/1.457356, 1989.

Saunders, S. M., Jenkin, M. E., Derwent, R. G., and Pilling, M. J.: Protocol for the development of the Master Chemical Mechanism, MCM v3 (Part A): tropospheric degradation of nonaromatic volatile organic compounds, Atmos. Chem. Phys., 3, 161-180, https://doi.org/10.5194/acp-3-161-2003, 2003.
Shannon, R. J., Blitz, M. A., Goddard, A., and Heard, D. E.: Accelerated chemistry in the reaction between the hydroxyl radical and methanol at interstellar temperatures facilitated by tunnelling, Nat. Chem., 5, 745-749, https://doi.org/10.1038/nchem.1692, 2013.

Simon, F. G., Schneider, W., and Moortgat, G. K.: UV absorption spectrum of the methylperoxy radical and the kinetics of its disproportionation reaction at $300 \mathrm{~K}$, Int. J. Chem. Kinet., 22, 791812, https://doi.org/10.1002/kin.550220802, 1990.

Tyndall, G. S., Wallington, T. J., and Ball, J. C.: FTIR product study of the reactions $\mathrm{CH}_{3} \mathrm{O}_{2}+\mathrm{CH}_{3} \mathrm{O}_{2}$ and $\mathrm{CH}_{3} \mathrm{O}_{2}+\mathrm{O}_{3}$, J. Phys Chem. A, 102, 2547-2554, https://doi.org/10.1021/jp972784h, 1998.

Tyndall, G. S., Cox, R. A., Granier, C., Lesclaux, R., Moortgat, G. K., Pilling, M. J., Ravishankara, A. R., and Wallington, T. J.: Atmospheric chemistry of small organic peroxy radicals, J. Geophys. Res.-Atmos., 106, 12157-12182, https://doi.org/10.1029/2000jd900746, 2001.

Wantuck, P. J., Oldenborg, R. C., Baughcum, S. L., and Winn, K. R.: Collisional quenching of $\mathrm{CH}_{3} \mathrm{O}\left(\mathrm{A}^{2} \mathrm{~A}_{1}\right)$, J. Phys. Chem., 91, 3253-3259, https://doi.org/10.1021/j100296a030, 1987.

Wen, Y., Segall, J., Dulligan, M., and Wittig, C.: Photodissociation of methanol at $193.3 \mathrm{~nm}$ : Translational energy release spectra, J. Chem. Phys., 101, 5665-5671, https://doi.org/10.1063/1.467352, 1994.

Wendt, H. R. and Hunziker, H. E.: Electronic absorption spectrum of $\mathrm{CH}_{3} \mathrm{O}$, J. Chem. Phys., 71, 5202-5205, https://doi.org/10.1063/1.438296, 1979.

Whalley, L. K., Furneaux, K. L., Goddard, A., Lee, J. D., Mahajan, A., Oetjen, H., Read, K. A., Kaaden, N., Carpenter, L. J., Lewis, A. C., Plane, J. M. C., Saltzman, E. S., Wiedensohler, A., and Heard, D. E.: The chemistry of $\mathrm{OH}$ and $\mathrm{HO}_{2}$ radicals in the boundary layer over the tropical Atlantic Ocean, Atmos. Chem. Phys., 10, 1555-1576, https://doi.org/10.5194/acp10-1555-2010, 2010.

Whalley, L. K., Edwards, P. M., Furneaux, K. L., Goddard, A., Ingham, T., Evans, M. J., Stone, D., Hopkins, J. R., Jones, C. E., Karunaharan, A., Lee, J. D., Lewis, A. C., Monks, P. S., Moller, S. J., and Heard, D. E.: Quantifying the magnitude of a missing hydroxyl radical source in a tropical rainforest, Atmos. Chem. Phys., 11, 7223-7233, https://doi.org/10.5194/acp11-7223-2011, 2011.

Whalley, L. K., Blitz, M. A., Desservettaz, M., Seakins, P. W., and Heard, D. E.: Reporting the sensitivity of laser-induced fluorescence instruments used for $\mathrm{HO}_{2}$ detection to an interference from $\mathrm{RO}_{2}$ radicals and introducing a novel approach that enables $\mathrm{HO}_{2}$ and certain $\mathrm{RO}_{2}$ types to be selectively measured, Atmos. Meas. Tech., 6, 3425-3440, https://doi.org/10.5194/amt-6-3425-2013, 2013.

Whalley, L. K., Stone, D., Hopkins, J., Holmes, R., Lee, J. D., Hamilton, J., and Heard, D. E.: Understanding in situ ozone production in the summertime through radical observations and modelling studies during the Clean air for London project, to be submitted, 2017.

Winiberg, F. A. F., Smith, S. C., Bejan, I., Brumby, C. A., Ingham, T., Malkin, T. L., Orr, S. C., Heard, D. E., and Seakins, P. W.: Pressure-dependent calibration of the $\mathrm{OH}$ and $\mathrm{HO}_{2}$ channels of a FAGE $\mathrm{HO}_{x}$ instrument using the Highly Instrumented Reactor 
for Atmospheric Chemistry (HIRAC), Atmos. Meas. Tech., 8, 523-540, https://doi.org/10.5194/amt-8-523-2015, 2015.

Winiberg, F. A. F., Dillon, T. J., Orr, S. C., Groß, C. B. M., Bejan, I., Brumby, C. A., Evans, M. J., Smith, S. C., Heard, D. E., and Seakins, P. W.: Direct measurements of $\mathrm{OH}$ and other product yields from the $\mathrm{HO}_{2}+\mathrm{CH}_{3} \mathrm{C}(\mathrm{O}) \mathrm{O}_{2}$ reaction, Atmos. Chem. Phys., 16, 4023-4042, https://doi.org/10.5194/acp16-4023-2016, 2016.
Zador, J., Taatjes, C. A., and Fernandes, R. X.: Kinetics of elementary reactions in low-temperature autoignition chemistry, Prog. Energ. Combust., 37, 371-421, https://doi.org/10.1016/j.pecs.2010.06.006, 2011. 